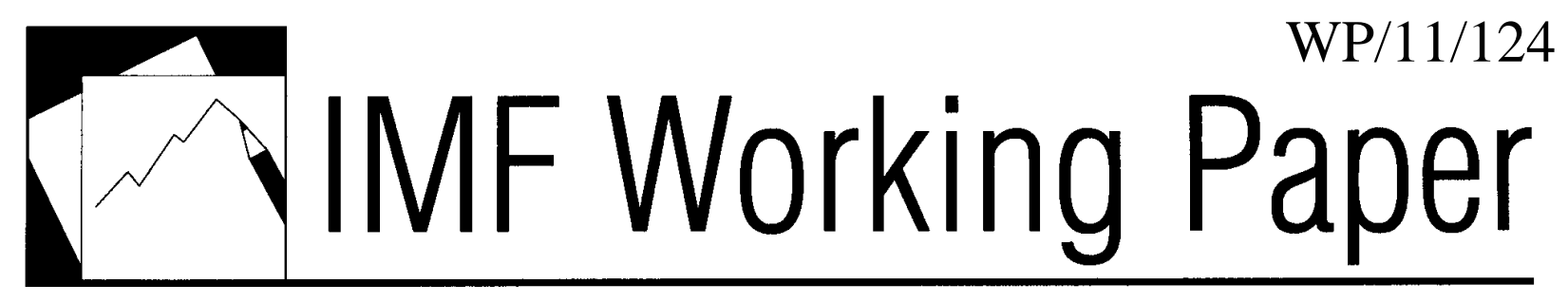

\title{
Reforming the Tax System to Promote Environmental Objectives: \\ An Application to Mauritius
}

Ian W.H. Parry 


\title{
IMF Working Paper
}

Fiscal Affairs Department

\section{Reforming the Tax System to Promote Environmental Objectives: An Application to Mauritius}

\author{
Prepared by Ian W.H. Parry ${ }^{1}$ \\ Authorized for distribution by Victoria Perry
}

June 2011

\begin{abstract}
Fiscal instruments are potentially among the most effective, and cost-effective, options for addressing externalities related to poor air quality, urban road congestion, and greenhouse gases. This paper takes a case study, focused on Mauritius (a pioneer in the use of green taxes) to illustrate how existing taxes, especially on fuels and vehicles, could be reformed to better address these externalities. We discuss, in particular, an explicit carbon tax; a variety of options for reforming vehicle taxes to meet environmental, equity, and revenue objectives; and a progressive transition to usage-based vehicle taxes to address congestion.
\end{abstract}

JEL Classification Numbers: Q56, Q58, H23, R48

Keywords: Mauritius; green taxes; global warming; congestion; vehicle taxes.

Author's E-Mail Address: iparry@imf.org

\section{This Working Paper should not be reported as representing the views of the IMF.} The views expressed in this Working Paper are those of the author(s) and do not necessarily represent those of the IMF or IMF policy. Working Papers describe research in progress by the author(s) and are published to elicit comments and to further debate.

\footnotetext{
${ }^{1}$ An earlier version of this paper was written as part of an Article IV consultation between the International Monetary Fund and the Mauritian authorities. I am grateful to Mahen Bheekhee, Martin Petri, Kenneth Small, and Katsiaryna Svirydzenka for helpful comments and suggestions.
} 


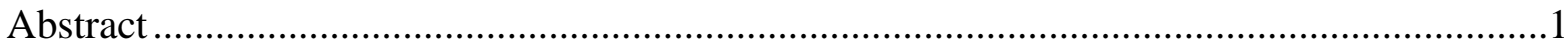

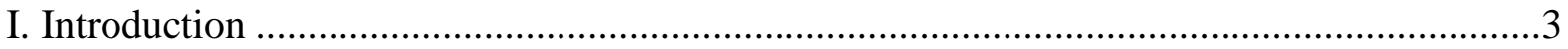

II. Conceptual Case for Environmental Taxes ....................................................................6

III. Assessment of Green Tax Options for Mauritius .............................................................

A. Climate Change and the Maurice Ile Durable (MID) ………..............................10

B. Preliminary Assessment of Automobile Externalities .............................................13

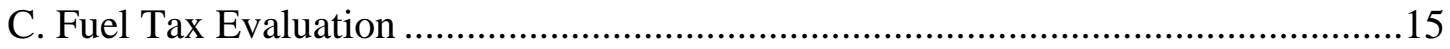

D. Tax Policies to Reduce Traffic Congestion …………..........................................17

E. Vehicle Ownership Taxes...................................................................................20

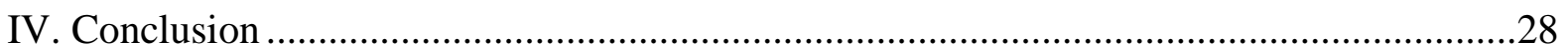

TABLES

1. Revenue from Energy and Environmental Taxes in Mauritius, ......................................10

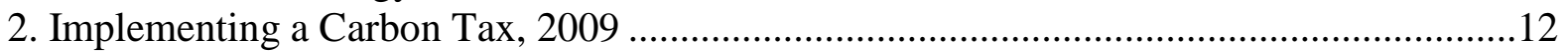

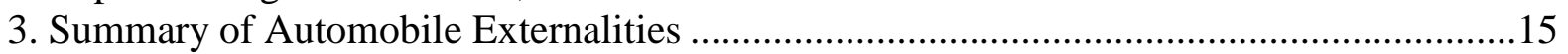

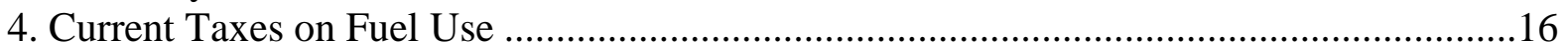

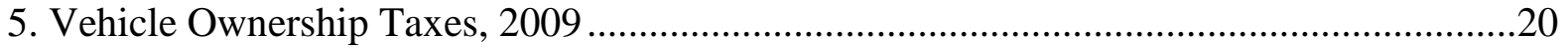

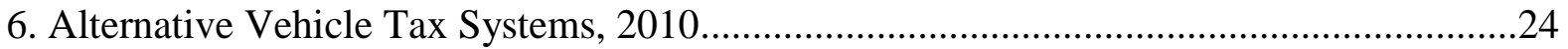

FIGURES

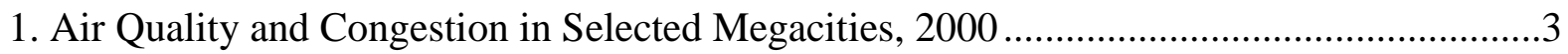

2. Revenues from Environmentally-Related Taxation, 2008 ................................................

3. Energy-Related CO2 Emissions Per Capita: Selected Countries ......................................11

4. Excise Taxes on Motor Fuels, Selected Countries, 2010..................................................16

5. Communication Aspects of GPS-Based Mileage Tolling ..................................................18

BOXES

1. Experience with Congestion Pricing in other Countries ...................................................19

APPENDIX

Some Details on Calculations Underlying Section III ......................................................29

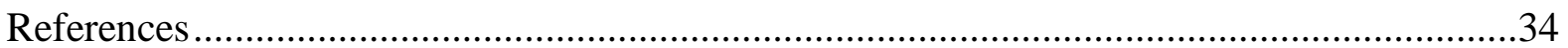




\section{INTRODUCTION}

The problems of poor air quality and traffic congestion are especially severe in urban centers of the developing world. Although Los Angeles is often ranked as the most polluted and congested city in the United States (e.g., Schrank and others, 2010), ambient particulate concentrations, as well as the average time required to travel a mile, are much greater in Delhi, Cairo, Mexico City, Jakarta, and Beijing (Figure 1). Pollution and urban gridlock can constrain economic growth through adverse effects on human health and productivity and wasted time. Climate change is yet another problem that may hinder future development in vulnerable countries.

Figure 1. Air Quality and Congestion in Selected Megacities, 2000

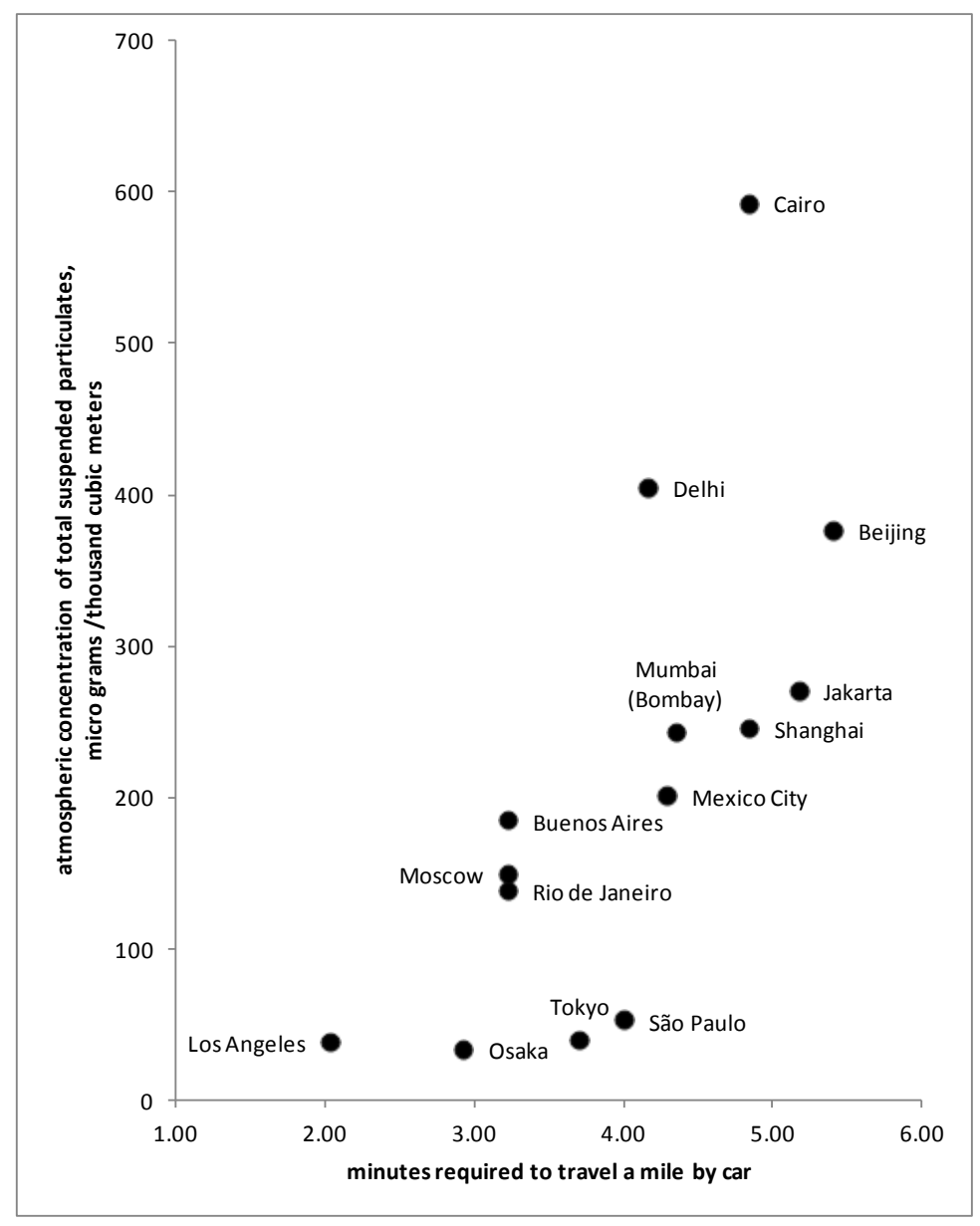

Source: Gurjara and others (2008); and International Association of Public Transport (2007).

1/ Suspended Particulates include organic and inorganic particles (e.g., dust, sand, metals, wood particles, smoke), PM-10 (coarse particulates less than 10 micro-meters in diameter), and PM-2.5 (fine particulates less than 2.5 micro-meters in diameter). 
Local pollution, traffic congestion, and climate change are all classic externality problems requiring corrective action by the government. Given the seriousness of these problems, it is critically important to address them with policy instruments that exploit, in a least-cost manner, all the different behavioral responses throughout the economy that can help alleviate these problems. As discussed below, fiscal instruments are often the most effective policy in this regard, while at the same time mobilizing valuable government funds, which is a major concern for developing countries. ${ }^{2}$

However, to date there has been only limited use of environmental (or other corrective) taxes. Although many countries raise significant amounts of revenue from taxes that might in part be rationalized on environmental grounds (Figure 2), these taxes typically have only limited effects on externalities. For example, most of the revenues in Figure 2 reflect taxes on vehicles and motor fuels. These taxes are very blunt instruments for reducing traffic congestion because they do not vary across region, time of day, or according to prevailing congestion on the road where driving occurs. And vehicle taxes have only limited effects on pollution, as they do not reduce the intensity of vehicle use and, as discussed below, may provide only weak incentives for higher fuel economy.

This paper takes a case study to illustrate how existing fiscal systems might be reformed to better address major externality problems. We focus on Mauritius, one of the leaders in the use of innovative taxes to promote environmentally sustainable development. ${ }^{3}$ For example, Mauritius recently introduced a form of carbon taxation; motor fuel taxes are substantial; the government is considering reforms to vehicle ownership taxes that would better promote environmental objectives; Mauritius has substantially reduced use of plastic shopping bags through tax policy; and, following similar schemes in Singapore, London, and Stockholm, policymakers are considering plans to reduce traffic congestion in the capital Port Louis through road pricing.

Existing and proposed tax reforms in Mauritius are assessed with a focus on carbon taxation, tax policies to alleviate traffic congestion, fuel taxes, and a variety of options for reforming the system of vehicle ownership taxes. In particular, we argue for enacting an explicit tax on carbon dioxide $\left(\mathrm{CO}_{2}\right)$ emissions, for using a (revenue-neutral) "feebate" to cost-effectively increase fuel economy, and for combining it with an excise tax on vehicle sales prices to

\footnotetext{
${ }^{2}$ For example, achieving the Millennium Development Goals may require low-income countries to raise their tax-GDP ratios by around 4 percentage points (United Nations, 2005).

${ }^{3}$ The island of Mauritius is located in the Indian Ocean to the east of Madagascar. It has a population of 1.3 million and per capita income (measured in Purchasing Power Parity) of approximately US $\$ 13,000$ (World Bank, 2009).
} 
meet revenue and equity objectives. ${ }^{4}$ We also recommend converting the road tax into a tax on annual kilometers driven to initiate a progressive transition to a GPS-based pricing system where tolls vary across region and time of day according to congestion severity. (We do not consider taxation of local power plant emissions because, given their coastal location and prevailing wind patterns, their contribution to pollution exposure is relatively minor). Although focused on Mauritius, the discussion potentially serves as a template for other countries.

Figure 2. Revenues from Environmentally-Related Taxation, 2008

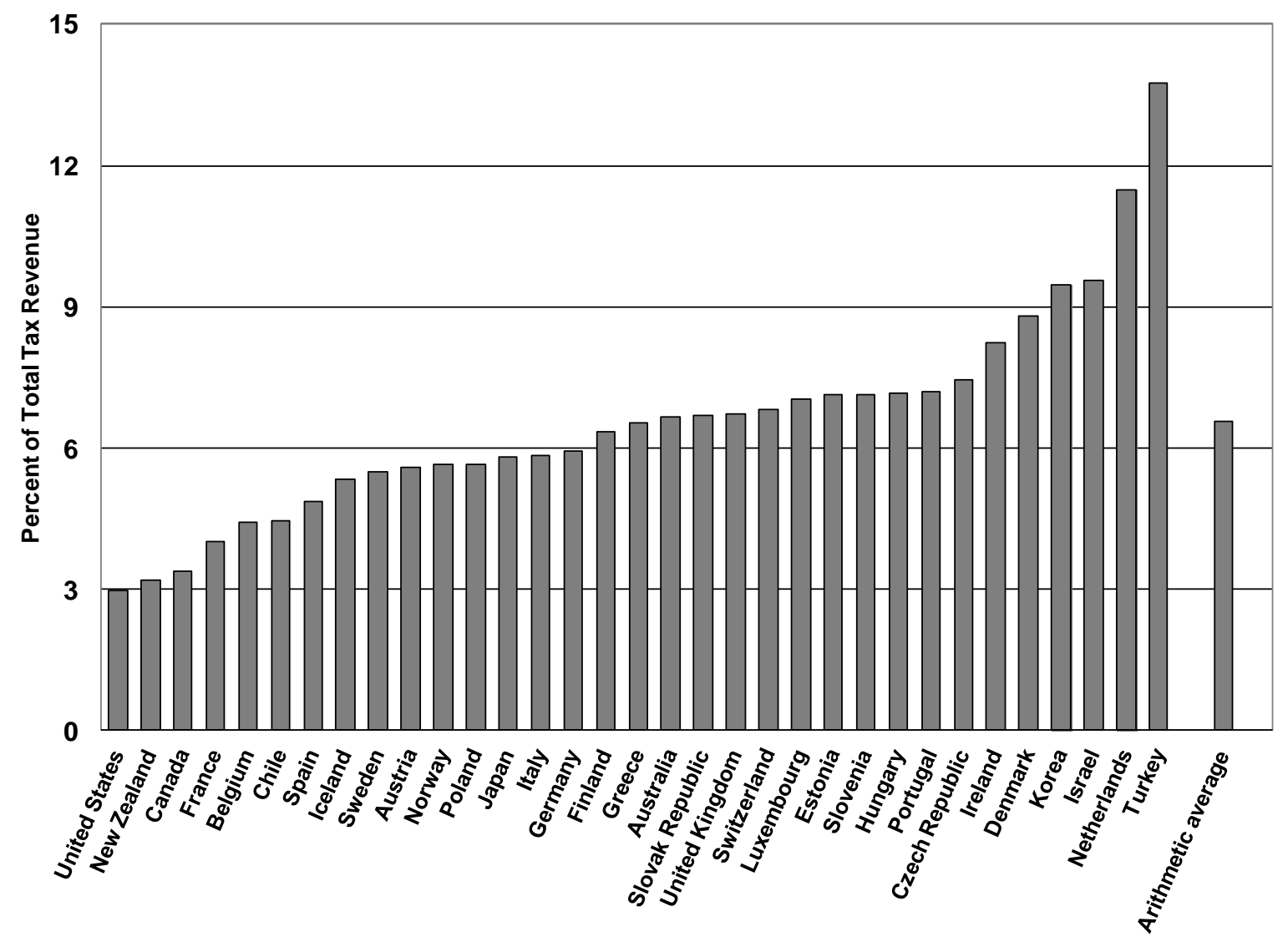

Source: OECD (2010), Figure 2.2.

The paper is organized as follows: the first section provides a brief conceptual rationale for using fiscal instruments to correct externalities. The following section presents the main analysis of green tax reform options for Mauritius. A final section offers concluding remarks.

\footnotetext{
${ }^{4}$ As discussed below, this feebate taxes the $\mathrm{CO}_{2}$ emissions per kilometer of vehicles in proportion to the excess over the average $\mathrm{CO}_{2}$ per kilometer for the new vehicle fleet and provides a corresponding rebate or subsidy for vehicles with below average $\mathrm{CO}_{2}$ per kilometer.
} 


\section{Conceptual Case for Environmental TaXes}

The production and use of certain goods and services in the economy generate broader societal costs, or externalities, that are not taken into account by households and firms. For example, fossil fuel combustion produces $\mathrm{CO}_{2}$, the main greenhouse gas, and also local emissions that are harmful to human health (e.g., Intergovernmental Panel on Climate Change, 2007; Dockery and others, 1993; and Schwartz, 1994). And motor vehicle use by one urban driver adds (slightly) to traffic congestion, thereby increasing delays for other road users (e.g., Santos, 2004a).

Fiscal instruments are the most natural policy for incorporating externalities into the prices of products, travel, and so on. If designed appropriately they potentially exploit all of the possible behavioral responses for reducing externalities throughout the economy. Regulatory approaches are generally less effective, because they exploit fewer of these responses. For example, as a carbon tax is passed forward into the price of fossil fuels, it will reduce $\mathrm{CO}_{2}$ emissions by encouraging a shift away from carbon-intensive fuels in power generation; a reduction in the use of energy-consuming products like vehicles and household appliances; and a shift towards more energy-efficient products (like cars with advanced fuel-saving technologies). Energy efficiency standards, in contrast, are far less effective: they exploit only the last of these emissions reduction opportunities (e.g., Krupnick and others, 2010).

Green taxes can also raise significant amounts of government revenue. For example, according to the IMF (2008), a $\$ 30$ per ton tax on $\mathrm{CO}_{2}$ emissions in 2020 would raise revenues equal to almost 4 percent of GDP in (fossil fuel intensive) Eastern European countries, and around 2.5 percent of GDP in Africa, China, and India. This fiscal dividend does not necessarily justify setting higher tax rates. Studies that examine the appropriate balance between environmental taxes and other taxes in the fiscal system generally find that green taxes should be set to (approximately) reflect environmental damages, with remaining general revenue requirements met through broader fiscal instruments like income taxes (e.g., Bovenberg and Goulder, 2002). ${ }^{5}$

An alternative, market-based approach to green taxes is a cap-and-trade system, like the European Union's Emissions Trading Scheme (ETS) to reduce greenhouse gases, a similar, smaller-scale system in New Zealand, and the program to reduce sulfur dioxide emissions from U.S. power plants. Under this approach, the government controls pollution through

\footnotetext{
5 These studies apply to developed countries, where revenue and distributional goals can, in principle, be met through the income tax and benefit system. In developing countries, receipts from the personal income tax are low, reflecting the relatively large informal sector and tax evasion and avoidance opportunities for the wealthy (IMF, 2011b). For these countries, from a practical perspective, some taxation of individual products could make sense on revenue and equity grounds.
} 
issuing a fixed amount of allowances that firms must hold to cover their emissions, and trading of allowances establishes a market price for allowances or emissions.

However, cap-and-trade systems can be inferior to emissions taxes. One reason is that they do not raise revenues if the allowances are given away for free (rather than auctioned), which has typically been the case in cap-and-trade programs to date. This forgoes the possibility of (potentially substantial) gains in economic efficiency from, for example, using new revenues to reduce broader tax distortions in the economy, such as disincentives for work effort and capital accumulation caused by taxes on the income from labor and capital (e.g., Parry and Williams, 2011). ${ }^{6}$ Furthermore, year-to-year volatility in allowance prices can be a problem under cap-and-trade systems (e.g., Pizer, 2003), because it can lead to too much abatement in some years (when the price is high) and too little in others (when the price is low). Price volatility may also deter investments in clean technologies with high up-front costs and long run payoffs. Green taxes, in contrast, can create a more stable environment for investments in clean technology, as firms and households know future emissions prices (assuming the policy is credible and sustained). ${ }^{7}$

Choosing the right base for green taxes is important, however. For example, if $\mathrm{CO}_{2}$ emissions are the source of the externality then taxing $\mathrm{CO}_{2}$ emissions from transport only will not address the externality in the power, residential, and industrial sectors. And as a matter of policy, emissions sources causing the same damage, such as $\mathrm{CO}_{2}$ emissions from different types of vehicles, should always be taxed at the same rate. For a given overall reduction in $\mathrm{CO}_{2}$, this will strike the right balance between, for example, encouraging some people to switch to smaller cars than they drive now, and others to buy more fuel efficient versions of vehicle models they prefer at present, since in all cases the rewards for reducing $\mathrm{CO}_{2}$ by an additional ton are the same.

A practical argument against green taxes is that they can harm industry competitiveness and the poor by raising the price of fuels, electricity, and so on (e.g., Metcalf, 2009). If possible however, it is generally better to help these groups through targeted assistance programs

\footnotetext{
${ }^{6}$ In fact, it has sometimes been claimed that environmental taxes can improve the environment and increase employment at the same time. However, the literature on environmental tax shifts generally casts doubt on this assertion. Any employment gains from revenue recycling tend to be offset as economic activity (and employment) contracts slightly in response to higher costs for energy and other products caused by the environmental tax (e.g., Bovenberg and Goulder, 2002; and Parry and Oates, 1999). In special cases, like work-related traffic congestion, employment can increase overall if reducing the externality itself has a positive feedback effect on labor supply, through raising the productivity of work effort relative to leisure.

${ }^{7}$ Price volatility can be addressed, at least in part, through provisions like allowing firms to bank or borrow allowances over time, or price collars (where the government steps in to sell allowances if the price reaches a ceiling level and buy allowances when the price reaches a floor level. Emissions allowances can also be auctioned to raise government revenue. All these provisions make cap-and-trade system behave more like (a more complicated and less efficient) environmental tax.
} 
(e.g., tax relief for low-income workers and vulnerable firms, winter supplements to pensioners to compensate for higher heating bills) rather than artificially holding down energy prices below levels warranted by externalities. Lower energy prices are a blunt way to help these target groups because they benefit all households (not just poor households) and all firms (not just those competing in global markets).

If markets work well, green taxes do not really need to be supplemented by additional policy instruments. So long as taxes are set at appropriate levels, they should cost-effectively exploit all the different possibilities for reducing externalities. In fact, supplementing green taxes with additional policies may do more harm than good if, from a cost-effectiveness perspective, this results in reducing "too much" of the externality through one avenue (e.g., fuel economy improvements) and "too little" through other avenues (e.g., reduced vehicle use).

However, complementary policies may be needed if market impediments prevent households and firms from adequately responding to the price signals created by green taxes. For example, if consumers are poorly informed about the energy savings from improvements in energy efficiency (e.g., of household appliances) or the reliability of new technologies (e.g., plug-in hybrid electric vehicles), then government information programs or perhaps transitory incentives to push the market penetration of these new technologies may be warranted. ${ }^{8}$ To take another example, transitory incentives to promote renewable energy sources might be needed if, because of technology "spillovers," investments in these technologies would be inadequate, even with emissions taxes. Such spillovers exist if later adopters of the technology benefit or "free ride" from experience at an early adopting firm providing information on how to operate the technology at lower cost. The justification for all these sorts of complementary policies needs to be evaluated on a case-by-case basis however, and usually by far the biggest source of net economic benefit will come from the tax itself rather than the supplementary instruments (e.g., Parry and others, 2003).

For most environmental (and other) externality problems, fiscal instruments are relatively straightforward to implement. For example, fossil fuels can be taxed at the point they enter the economy, and local emissions from industrial sources can be metered with continuous monitoring technologies installed in the smokestack (or inferred from fuel inputs if there are no end-of-pipe scrubbing technologies). There are exceptions, such as vehicle tailpipe

\footnotetext{
${ }^{8}$ Whether households under-invest in energy efficiency is contentious. Some (though not all) empirical studies for the United States find that consumers require very high implicit rates of return on energy-saving technologies, often in excess of 25 percent (e.g., Allcott and Wozny, 2009; Hausman, 1979; and Train, 1985). Some analysts believe this constitutes evidence that consumers misperceive energy efficiency benefits perhaps because of poor information. Another explanation, however, is that there might be hidden costs that make people reluctant to invest in energy efficiency, such as objectionable aspects of the quality of fluorescent lighting and high borrowing costs.
} 
emissions, whose individual sources are too numerous to monitor. In this case, however, the effects of an emissions tax can be approximately replicated through a combination of other instruments, namely a fuel tax and emissions-per-mile regulations (e.g., Eskeland, 1994).

In short, fiscal instruments have a potentially critical role to play in ameliorating the major environmental and other externalities and providing signals for the development of low-carbon and other technologies that will ultimately be needed to achieve environmental sustainability. But these instruments need to be carefully designed, in regard to both their scale and their breadth of coverage. The case for environmental taxes is also undermined if revenues are not used productively (e.g., to cut other distortionary taxes or fund spending projects with favorable benefit-cost ratios). And if poor households spend a disproportionately large share of their budgets for energy, green tax reforms can have adverse distributional consequences that may require compensation through other, more targeted measures.

\section{Assessment of Green TAX Options fOr MAURitius}

Excise taxes on petroleum products and on motor vehicles are the two largest sources of revenue raised from taxes in Mauritius that might be rationalized on environmental grounds. In fiscal year 2008/09, fuel excise taxes raised Rs 2,213 million (including Rs 239 million from the Maurice Ile Durable levy discussed below), or 4.7 percent of total tax collections, while vehicle excise taxes (excluding registration fees and road taxes) raised Rs 1,852 million, or 3.9 percent of total tax collections (Table 1). Our main focus will be on these taxes. Excise taxes on plastic products (bottles, bags, and cans), an "environmental protection fee" (a tax on hotels, guest houses, and tourist residences), and a "solidarity levy," each contributed $0.2-0.3$ percent to total tax revenue, while a "passenger fee" contributed 1.2 percent to total tax revenues. ${ }^{9}$

This section provides our main discussion of existing green taxes in Mauritius and possibilities for tax reform. We begin with the Maurice Ile Durable (MID) levy, which is very close to a tax on $\mathrm{CO}_{2}$ emissions. We then turn to the transportation sector and discuss rough estimates of the size of transportation externalities; existing gasoline and diesel taxes; tax policies to reduce traffic congestion; the reform of vehicle ownership taxes; and using the tax system to promote car insurance reform. Finally, we briefly comment on some broader potential applications of green taxes.

\footnotetext{
${ }^{9}$ The passenger fee reflects specific charges on international flights, with some of the revenue earmarked for tourism and financing airport related services. The solidarity levy is another tax on airline tickets (1 Euro on economy class and 2 Euros on business and first class passengers) that is part of an international effort to raise money to combat HIV/AIDS, malaria, and tuberculosis in poor countries.
} 
Table 1. Revenue from Energy and Environmental Taxes in Mauritius, Fiscal Year 2008/09

\begin{tabular}{lrc}
\hline & Rs million & $\begin{array}{c}\text { Percent of } \\
\text { Total Tax Revenue }\end{array}$ \\
\hline $\begin{array}{l}\text { Excise duties on petroleum products } \\
\text { of which MID (green tax) levy on petroluem products and coal }\end{array}$ & 2,213 & 4.7 \\
Excise duties on motor vehicles and motor cycles & 239 & 0.5 \\
Excise tax on plastic products & 1,852 & 3.9 \\
Environmental protection fee & 124 & 0.3 \\
Passenger fee & 159 & 0.3 \\
Temporary solidarity levy & 572 & 0.2 \\
Total & 101 & $\mathbf{1 1 . 1}$ \\
\hline
\end{tabular}

Source: Mauritius Revenue Authority (2009), Tables 1, 7, and 9.

\section{A. Climate Change and the Maurice Ile Durable (MID)}

On a per capita basis, energy-related $\mathrm{CO}_{2}$ emissions have increased substantially in Mauritius over the last three decades, with increasing use of petroleum products and, more recently, coal. Per capita emissions were 3.6 tons in 2008, compared with 0.9 tons in 1980. Nonetheless, per capita emissions are still low relative to those in the United States, United Kingdom, and South Africa (Figure 3).

The MID is a tax on fossil fuels established in July 2008 to finance clean energy projects (e.g., subsidies for compact fluorescent lamps and solar water heaters). For 2011, the MID levy has been doubled to Rs 0.30 (or US\$0.01) per kilogram for coal, Rs 0.30 per kilogram of liquefied petroleum gas (LPG), and Rs 0.30 per liter for other petroleum products. ${ }^{10}$ These taxes are essentially passed forward into the price of fuels. The biggest price impact in percentage terms is for coal (given its high carbon content), whose price has risen 9.4 percent relative to 2009 prices; the price of fuel oil has risen 1.8 percent, and other fuel prices roughly 1 percent (Table 2 ).

\footnotetext{
${ }^{10}$ Figures in Mauritius rupees are converted using a rate of Rs 30 per US $\$ 1$.
} 


\section{Figure 3. Energy-Related $\mathrm{CO}_{2}$ Emissions Per Capita: Selected Countries}

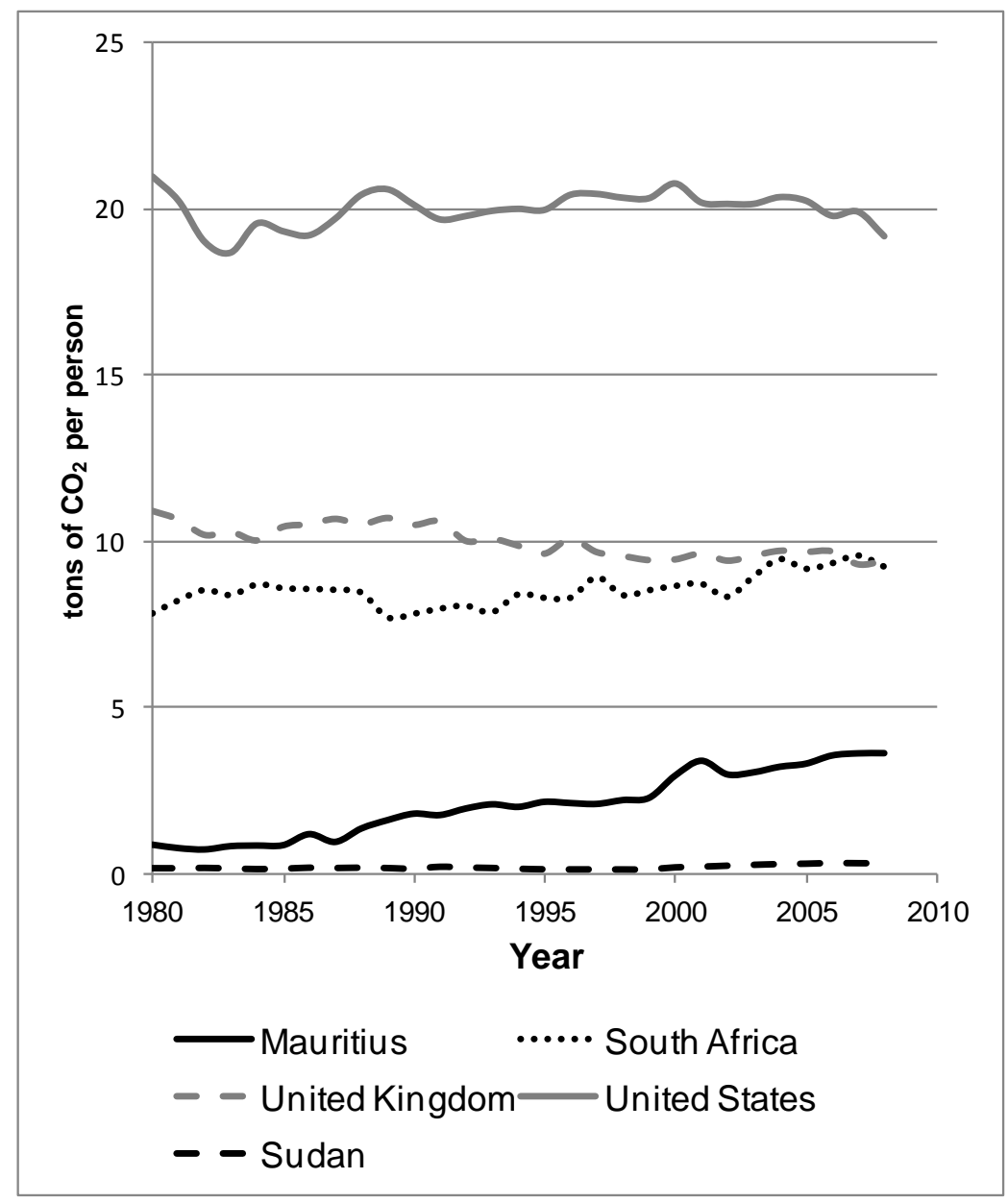

Source: United States, Energy Information Administration (2010).

Although its main motivation is to raise money, the MID is actually very close in design to the ideal tax for mitigating $\mathrm{CO}_{2}$ emissions. ${ }^{11}$ Converting the MID into an explicit carbon tax would involve setting a tax on each fuel equal to its $\mathrm{CO}_{2}$ coefficient (i.e., the $\mathrm{CO}_{2}$ produced by combusting a unit of the fuel) times the $\mathrm{CO}_{2}$ price. To maintain projected MID revenues for 2011 (Rs 577 million) would require a tax rate of approximately Rs 118 per ton of $\mathrm{CO}_{2}$. In fact, the pattern of fuel taxes implied by this carbon tax is actually extremely close to that under the MID at present (Table 2). However, re-defining the MID as a $\mathrm{CO}_{2}$ tax would make

\footnotetext{
${ }^{11}$ The MID is better than the EU ETS, in the sense that is focused upstream on all fossil fuels and therefore covers all potential sources of energy-related $\mathrm{CO}_{2}$; the emissions price is fixed rather than variable; and it raises revenue. The ETS is a downstream program focused on large stationary emissions sources (e.g., power plants) and fails to cover about 40 percent of emissions; prices have been volatile; and to date, allowances have largely been given away rather than auctioned (e.g., Ellerman and Joskow, 2008). Although a handful of countries have implemented or are considering some form of carbon tax, only the British Columbia tax so far comes close to the economically ideal policy (Republic of South Africa National Treasury, 2010, Table 8).
} 
climate policy in Mauritius more transparent, facilitate comparison with emissions pricing policies in other countries, and provide a valuable example for others to follow.

Table 2. Implementing a Carbon Tax, 2009

\begin{tabular}{|c|c|c|c|c|c|c|}
\hline \multirow[b]{2}{*}{ Fuel } & \multirow[b]{2}{*}{$\begin{array}{c}\text { Physical } \\
\text { Unit }\end{array}$} & \multirow[b]{2}{*}{$\begin{array}{c}\mathrm{CO}_{2} \\
\text { Coefficient }\end{array}$} & \multirow{2}{*}{$\begin{array}{l}\text { Consumption } \\
\text { Million Units } \\
2010\end{array}$} & \multicolumn{2}{|c|}{ Fuel Taxes, Rs per Unit } & \multirow{2}{*}{$\begin{array}{l}\text { Percent Price } \\
\text { Increase Due } \\
\text { to MID }\end{array}$} \\
\hline & & & & MID & $\begin{array}{c}\mathrm{CO}_{2} \text { Tax, Rs/t } \\
118\end{array}$ & \\
\hline Coal & kg & 0.0023 & 660 & 0.30 & 0.28 & 9.4 \\
\hline Fuel oil & liter & 0.0027 & 381 & 0.30 & 0.32 & 1.8 \\
\hline Gasoline & liter & 0.0023 & 153 & 0.30 & 0.28 & 0.8 \\
\hline Diesel & liter & 0.0027 & 376 & 0.30 & 0.32 & 0.9 \\
\hline Kerosene & liter & 0.0027 & 291 & 0.30 & 0.32 & 0.8 \\
\hline LPG & kg & 0.0030 & 63 & 0.30 & 0.35 & 1.2 \\
\hline Projected & venue fo & 011, Rs millio & & 577 & 577 & \\
\hline
\end{tabular}

Source: Mauritius, Central Statistics Office (CSO) (2010b), Tables 2.7 and 2.8. $\mathrm{CO}_{2}$ coefficients are from http://bioenergy.ornl.gov/papers/misc/energy_conv.html $\left(1\right.$ tonne carbon $=3.67$ tonnes $\left.\mathrm{CO}_{2}\right)$ and Devarajen Vithilingum (Ministry of Environment and Sustainable Development, Mauritius).

1/ Revenue projections do not account for (modest) price-induced changes in fuel demand.

As regards appropriate scale, a $\mathrm{CO}_{2}$ tax of Rs 118 (US\$4) per ton is on the low side, at least according to literature on the marginal damages from $\mathrm{CO}_{2}$ emissions. This damage reflects the worldwide impacts from the future climate change caused by an additional ton of emissions today (e.g., losses to world agriculture, the costs of protecting against rising sea levels, health effects from increased prevalence of disease and heat waves, loss of species and ecosystems, and risks of large GDP losses from extreme climate scenarios). ${ }^{12}$ Economists have attempted to obtain some ballpark sense of these potential damages, and based on this evidence a recent U.S. inter-agency review (United States, Interagency Working Group on Social Cost of Carbon, 2010) recommends using a value of US\$21 for 2010 emissions, rising about 2 to 3 percent a year in real terms. ${ }^{13}$ For comparison, the price of $\mathrm{CO}_{2}$ in the ETS is currently equivalent to about US\$20 per ton. ${ }^{14}$

\footnotetext{
${ }^{12}$ These damages are the same for all emissions releases, across all countries.

${ }^{13}$ This figure is contentious, however, given disagreement over the appropriate rate at which to discount impacts from today's emissions on future, unborn generations. And some analysts believe that these estimates to not adequately handle the risks of extreme climate change outcomes. In fact, emissions prices consistent with limiting projected warming to $2^{\mathrm{O}} \mathrm{C}$ (the aspirational goal agreed to at the last round of climate talks in
} 
To express the carbon damage estimate in terms of local purchasing power, we need to use the PPP exchange rate rather than the market exchange rate. This gives our recommended carbon tax of (approximately) Rs 360 per ton. ${ }^{15}$ It might be argued that a lower carbon tax is warranted in Mauritius than in the United States, based on the "common but differentiated" principle of the United Nations Framework Convention on Climate Change - that is, rich countries should bear a disproportionately larger burden of mitigation responsibilities. ${ }^{16}$

Even if the $\mathrm{CO}_{2}$ tax were increased up to Rs 360 per ton, it would have only modest effects on economy-wide $\mathrm{CO}_{2}$ emissions in Mauritius, however, because of limited abatement opportunities. $\mathrm{CO}_{2}$ emissions in Mauritius were 3.4 million metric tonnes in 2009, with 59 percent of emissions coming from fuel combustion in power generation, 25 percent from transportation, and 10 percent from manufacturing (Mauritius CSO, 2010a, Table 15). In the power sector, for example, coal (the most carbon-intensive fuel) accounted for 48.3 percent of generation in 2008, fuel oil (the next most carbon intensive fuel) 20.5 percent, bagasse (a zero-carbon renewable fuel from residual sugar cane that is co-fired with coal) 26.5 percent, and hydro 4.2 percent (Mauritius CSO, 2009, Tables 3.6 and 3.7). However, shifting from coal to (imported) natural gas is not feasible; generation from a nuclear plant (which emits no carbon) would greatly exceed needed demand; and clean domestic generation sources (bagasse and hydro) are already near capacity. ${ }^{17}$ Nonetheless, some response could be expected and the additional revenues could be used to reduce other more distortive taxes.

\section{B. Preliminary Assessment of Automobile Externalities}

We begin our discussion of automobile policies by providing some, albeit very crude, estimates of the major automobile externalities - pollution, congestion, and traffic accidents. $^{18}$

Cancun, Mexico 2010), even if implemented globally, would be considerably higher than the above damage estimate (e.g., Clarke et al., 2009), though this goal is rapidly becoming infeasible.

${ }^{14}$ Applying the 2010 dollar/Euro PPP exchange rate to the $\mathrm{CO}_{2}$ price in Euros from www.pointcarbon.com.

${ }^{15}$ We assume the PPP rate is Rs 18 to US $\$ 1$ from the World Economic Outlook database.

${ }^{16}$ Using the PPP exchange rate instead of the market exchange rate goes into the direction of burden-sharing, since poorer countries usually have more appreciated PPP exchange rates, reflecting the fact that non-traded goods tend to be cheaper in poorer countries. Using the market exchange rate would result in a carbon tax of approximately RS 600 per ton. Of course, from a global perspective it would be important to calculate the externality from $\mathrm{CO}_{2}$ in a PPP context if one uses PPP exchange rates for converting.

${ }^{17}$ Furthermore, because the island is made of volcanic rock, this would appear to rule out use of carbon capture and storage technologies.

${ }^{18}$ Road wear-and-tear is not assessed because this externality is a rapidly rising function of a vehicle's axle weight and is therefore primarily caused by heavy-duty trucks rather than cars (e.g., United States, Federal Highway Administration, 2000). 
Easily the largest component of local pollution damage estimates is from human mortality, mostly caused by fine particulates (small enough to reach lung tissue) formed in the atmosphere following chemical reactions with oxides of nitrogen $\left(\mathrm{NO}_{x}\right)$ and volatile organic compounds (VOCs). ${ }^{19}$ For the United States, local pollution/health effects have been estimated by combining models of emission rates for different vehicles with local air quality models (as influenced by local wind speeds and topography), then linking local air quality to health (and other) impacts using local data on population exposure and dose-response models, and finally attaching a monetary value to the physical impacts (e.g., National Research Council, 2009; and Muller and Mendelsohn, 2007).

Summarizing the literature, Small and Verhoef (2007, pp. 104-5), put local pollution damages, averaged across the United States, at the equivalent of US $\$ 0.007$ per vehicle kilometer, and the National Research Council (2009, Table 3.3), put damages at about US\$0.005 per vehicle kilometer for a gasoline vehicle (excluding emissions during vehicle manufacture). As discussed in the Appendix, we extrapolate these estimates to Mauritius using the PPP exchange rate, making some rough adjustments for differences in people's willingness to pay to avoid mortality risks and vehicle emission rates. The result is a (ballpark) damage figure of Rs 0.08 per kilometer. ${ }^{20}$

For global pollution, we use the above value (Rs 360 per ton), multiply by the $\mathrm{CO}_{2}$ coefficient for gasoline (0.0023 tonnes per liter), and divide by fuel economy (13 kilometers per liter or 30 miles per gallon), to obtain damages of Rs 0.06 per kilometer. ${ }^{21}$

To take account of congestion in setting efficient transport taxes, we need an estimate of the marginal costs of traffic congestion, both in specific areas like Port Louis and averaged across urban and rural areas. The marginal cost of congestion reflects the increase in travel time costs to other road users as a result of the additional congestion due to extra driving by an individual motorist. We obtain some broad sense of marginal congestion costs based on assumptions about how extra traffic affects travel speeds (and hence the average delay experienced by other road users because of congestion) and how much people are willing to pay to avoid increases in travel time. Our rudimentary estimate of marginal congestion cost is Rs 2.1 per kilometer for the nation as a whole, and Rs 12 per kilometer for peak driving in Port Louis (see Appendix).

\footnotetext{
${ }^{19}$ Other effects include impaired visibility, reduced crop yields, building corrosion, and morbidity (chronic bronchitis, asthma, and other respiratory and cardiovascular diseases).

${ }^{20}$ A more sophisticated assessment would adjust for other factors like differences in population exposure, in the composition of the exposed population (i.e., the fraction of the population that is vulnerable to pollution-health effects because of asthma or other pre-existing conditions), and in local topological and climatic factors affecting pollution dissipation.

${ }^{21}$ Fuel economy data were obtained from the National Transport Authority of Mauritius.
} 
Accident costs are another large side effect of vehicle use. Although some of these costs might be taken into account by individual drivers (e.g., injury risks in single-vehicle collisions) other costs are usually viewed as externalities (e.g., injury risks to pedestrians, property damage borne by third parties). We put the external accident cost about Rs 0.8 per kilometer driven for the average vehicle, where this cost is dominated by fatality risks (see Appendix).

In sum (see Table 3), congestion seems to be the most serious externality associated with car use. External costs per kilometer driven are 15 times the combined costs from local pollution and $\mathrm{CO}_{2}$ per kilometer. Accidents are also a sizeable externality, however.

Table 3. Summary of Automobile Externalities (Rs per km)

\begin{tabular}{ll}
\hline Local pollution & 0.08 \\
Global warming & 0.06 \\
Traffic congestion & 2.10 \\
Accidents & 0.80 \\
\hline
\end{tabular}

Source: See text and Appendix.

\section{Fuel Tax Evaluation}

The current excise tax on gasoline (which was increased by 10 percent in the 2011 budget) is Rs 10.8 per liter. However, a variety of other levies (e.g., for contributions to road development and cross subsidies for rice, flour, and LPG) increase the effective tax to Rs 17.8 per liter (see Table 4). Similar levies imply that the effective tax on diesel is Rs 10.25 per liter, even though the excise tax is only Rs 3.3 per liter. These tax levels are broadly in the middle of those shown for selected OECD countries in Figure 4 (where taxes are converted using market exchange rates): they are much higher than those in the United States and Canada, but lower than rates in some European countries.

Fuel taxes are not well-suited to reducing traffic congestion and traffic accidents because the tax is the same whether motorists drive in urban or rural areas, travel at peak or off-peak periods, or have high or low collision risks. Furthermore, a large portion of the behavioral response to fuel taxes comes from fuel economy improvements, which do nothing to reduce congestion and accidents. Nonetheless, until more finely-tuned instruments are widely implemented, it is still appropriate to take into account reductions in these externalities in assessing the appropriate level of fuel taxes. 
Table 4. Current Taxes on Fuel Use, Rs per Liter

\begin{tabular}{lcc}
\hline & Gasoline & Diesel \\
\hline Excise & 10.80 & 3.30 \\
MID & 0.30 & 0.30 \\
Contribution to road development & 1.85 & 1.75 \\
Hedging & 3.00 & 3.00 \\
Contribution to subsidy for LPG, flour, and rice & 1.50 & 1.50 \\
Contribution to administration of State Trading Corporation & 0.35 & 0.40 \\
Total & $\mathbf{1 7 . 8 0}$ & $\mathbf{1 0 . 2 5}$ \\
\hline
\end{tabular}

Source: Mauritius, State Trading Corporation (www.stcmu.com).

Figure 4. Excise Taxes on Motor Fuels, Selected Countries, 2010

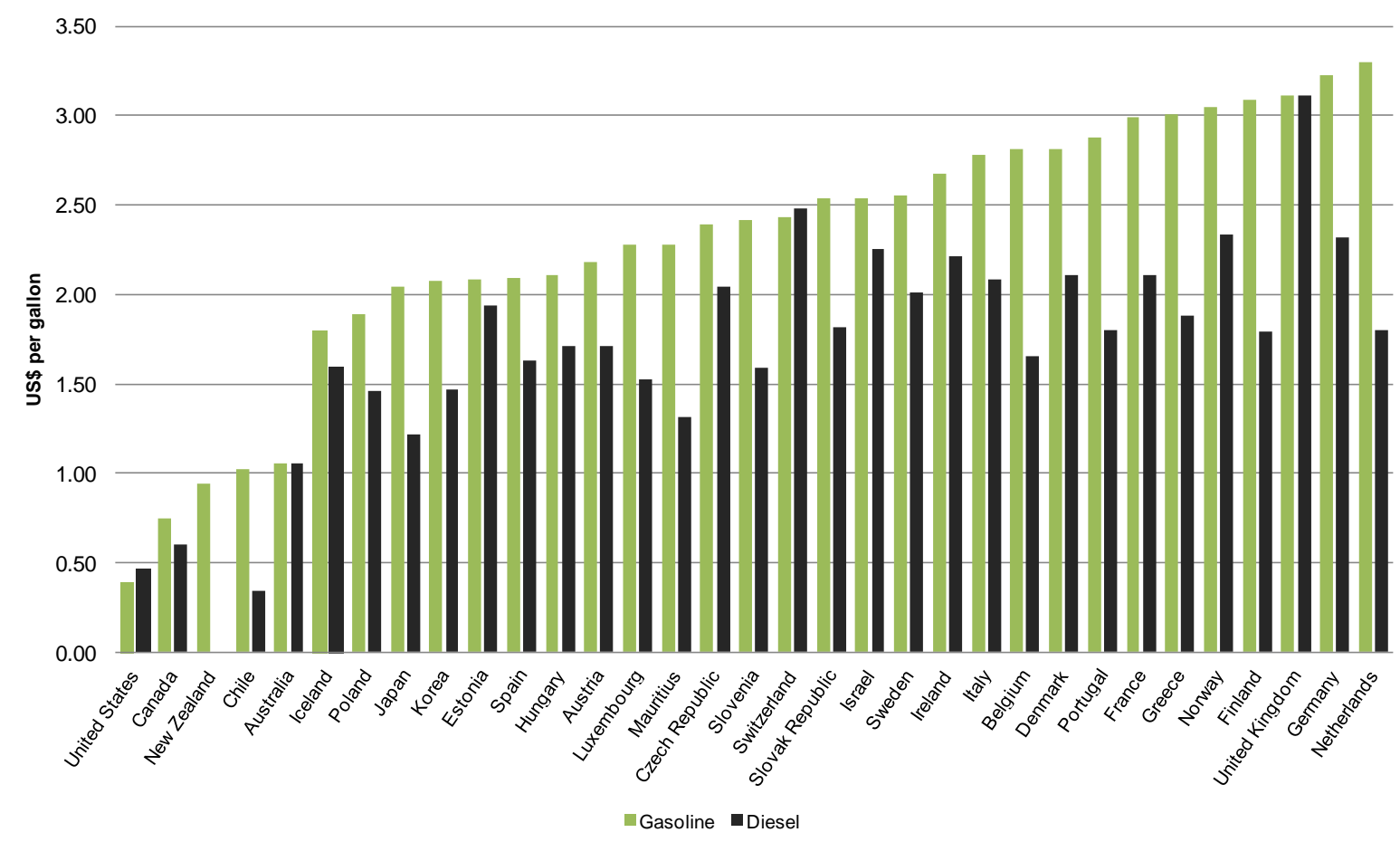

Source: OECD (2010), Figure 2.5, and Table 4 above.

The Appendix provides a calculation of the level of gasoline taxes warranted on externality grounds, using the above values for Mauritius. Given the tentative nature of our estimates, this calculation should be viewed with caution. Nonetheless, our estimate is that current gasoline tax levels appear to be fairly close to their appropriate levels - our optimal gasoline tax estimate is Rs 15.6 per liter (about Rs 2.5 below the current tax). 
We lack the data to assess optimal diesel fuel taxes, given that diesel is used by multiple vehicle types including buses, commercial trucks and farm vehicles. But lower taxes on diesel fuel compared with gasoline might well be efficient, to the extent that agricultural vehicles are driven disproportionately in rural (uncongested areas) and buses on net reduce congestion by diverting some people out of cars. ${ }^{22}$

\section{Tax Policies to Reduce Traffic Congestion}

Dealing with traffic congestion through further expansion of the road system is increasingly difficult given that the most congested city, Port Louis, is already very built-up (e.g., Menon, 2004). In any case, road building is partly self-defeating, in that a denser road network ultimately encourages more people to drive (e.g., Downs, 1992). Building a light rail system and a ring road may make sense, but without any price on road usage to address the congestion externality roads would still be used excessively by motorists.

Ultimately, the best way to reduce nationwide traffic congestion for a given existing road infrastructure, would be to use Global Positioning System (GPS) technology to charge every motorist per kilometer driven on congested roads, where the per-kilometer charge rises and falls during the course of the rush hour (TRB, 2006). This type of tax system would exploit all of the possible behavioral responses for reducing congestion-encouraging people to commute earlier or later to avoid the peak of the rush hour, to car pool, to use public transport rather than drive, to reduce their overall number of trips, to re-locate jobs out of busy downtown areas etc. Although most people would continue to drive, despite these tolls, typically it only takes a fairly modest reduction in the number of vehicles to significantly improve travel speeds on clogged roads (e.g., Lindsay and Verhoef, 2000).

Figure 5 illustrates communications aspects of GPS-based tolling, where information on driving behavior, monitored by satellite, is transmitted to a private service provider to be aggregated and then forwarded to a collection office for tax assessment, and then finally sent to the vehicle owner. Privacy issues are a potentially important concern however, and would need to be addressed through strict legal requirements on information-collection agencies. ${ }^{23}$

\footnotetext{
${ }^{22}$ The carbon content of diesel fuel is moderately (about 16 percent) higher than gasoline though, as already mentioned, other externalities dominate global warming.

${ }^{23}$ GPS-based tolling systems have been introduced for trucks in Germany and seriously studied, but not yet implemented, in the United Kingdom and Holland for cars. Another congestion-mitigation policy is "Today Don't Drive" programs, where vehicles can be driven in the downtown area only on certain days of the week. But these programs can be evaded if households use multiple vehicles (Davis 2008) and are inefficient. A further possibility involves reserving premium lanes for high-occupancy vehicles (HOVs) to encourage carpooling. However, HOV lanes have had limited success in the United States (e.g., Safirova and others, 2004) because some HOV passengers would not otherwise have driven on their own (e.g., children, people who would otherwise use transit). Moreover, HOV lanes may result in under-use of scarce road capacity if traffic flows on them are much smaller than those on other (heavily congested) freeway lanes.
} 


\section{Figure 5. Communication Aspects of GPS-Based Mileage Tolling}

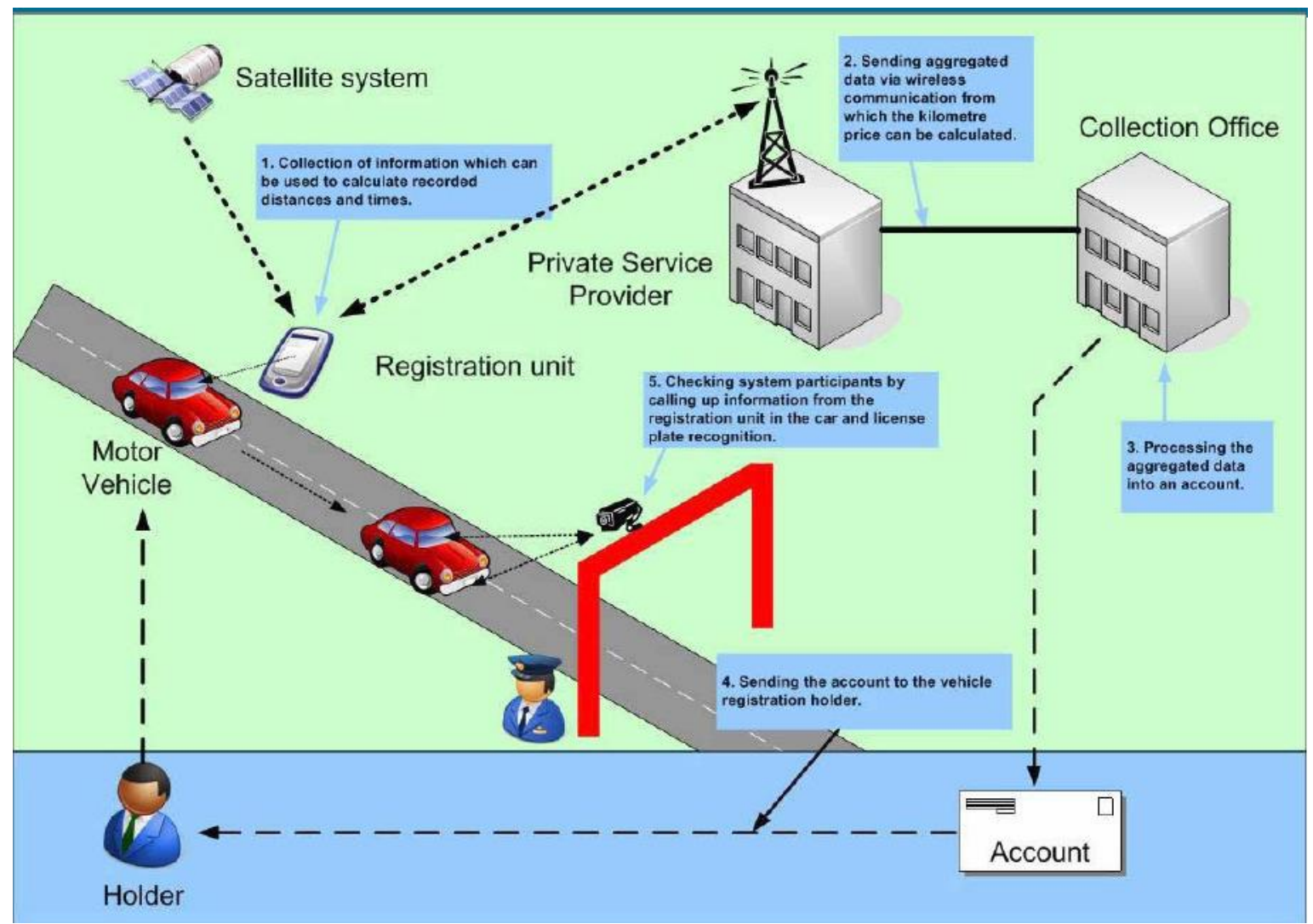

Source: Meurs (2011).

Until a comprehensive, GPS-based system becomes feasible, in the near term, probably the best practical pricing approach for Port Louis, which has severe commuter-related congestion at entries to the urban core in the morning and exits in the evening, would be some form of cordon toll around the downtown center. Under this approach, drivers pay (electronically) as they pass points in the road network that form a cordon around the city center. Ideally, the cordon toll at peak period should be set to reflect the external costs of congestion from a motorist driving within the tolled area, equal to the marginal external cost per kilometer (Rs 12 according to our calculations) times the average trip distance (in and out) of the tolled area. $^{24}$

Cordon-pricing is inefficient in that the same fee is imposed regardless of distance travelled (the longer the trip, the more a motorist contributes to congestion) and these schemes can also exacerbate congestion elsewhere, as people change their routes to bypass the pricing region. Despite this, pricing schemes in Singapore, London, and Stockholm appear to have

\footnotetext{
${ }^{24}$ This is approximately the diameter of the tolling area, if the average motorist drives to the center and back.
} 
been reasonably successful (see Box 1). Nonetheless, a cordon pricing scheme only addresses congestion on a localized basis (in the downtown core) - GPS-based tolling is needed to make optimal use of the nationwide road network.

\section{Box 1. Experience with Congestion Pricing in other Countries}

The first attempt to use road pricing for congestion was Singapore's area license (or day-pass), introduced in 1975. The scheme dramatically reduced congestion and raised travel speeds within the restricted zone, but congestion initially increased substantially outside of the zone (e.g., Small and Gómez-Ibáñez, 1998). In part, this problem was later addressed through supplementary tolls on major roads leading up to the restricted zone. Additionally, in 1998, Singapore replaced the area licensing with a toll debited electronically from smart cards on certain links, with the objective of maintaining an average speed of 30-40 miles per hour on expressways and 12-18 miles per hour on major roads (Santos 2010). Charges rise and fall in 30-minute steps during peak periods, based on congestion levels observed in the previous quarter.

Norway experimented with cordon tolling, though with little effect on congestion because the stated objective of the policy was to raise transportation revenue rather than deter congestion.

Congestion pricing has been given a large boost by its relatively successful implementation in London. An area licensing scheme was introduced in 2003 and was then extended to the west in 2007. All vehicles entering, leaving, driving, or parking on a public road inside the 15 square mile charging zone between 7:00 a.m. and 6:00 p.m. on weekdays must pay a daily congestion charge of $£ 8$ (Rs 400 ). Collection is by video cameras at checkpoints into and within the priced area that record each vehicle's license plate—drivers who have not prepaid are mailed a penalty amounting to $£ 60$ or more. In the first two years the policy reduced congestion (defined by the difference between the observed and free-flow travel rate) by 30 percent within the priced zone, without causing excessive congestion elsewhere in network (TfL 2008). Largely, this is because at least half of the diverted auto trips reflected people switching to mass transit, and only about a quarter were diverted to other roads in the network (Small and Verhoef 2007, pp. 151). However, by 2008, average speeds had fallen back to pre-charging levels due to an increase in traffic from vehicles exempt from the charge and the diversion of some of the road network for the exclusive use of buses, pedestrians, and cyclists (TfL 2008). Nonetheless, despite operating costs of about $£ 100$ million (Rs 5,000 million) per year, Santos (2010) estimates that the scheme still produces net economic benefits of about $£ 150$ million (Rs 7,500) per year. Although vehicle exemptions reduce program efficiency, they have helped with public and political acceptability.

Stockholm implemented a cordon toll in 2007 covering an area of about 36 square kilometer (again, enforcement is based on number plate recognition). The fee for passing the cordon during charging hours, either way, varies across time of day from between SEK 10 and 20 (Rs 45 or 90) though some vehicles are exempt (e.g., emergency vehicles, buses, motorcycles, alternative fuel vehicles). Congestion initially dropped by 50 percent on the main routes approaching the city center, and 20 percent within the city center, though there has been some deterioration recently. Still, studies suggest the scheme produces annual net benefits of around SEK 654 (Rs 2,800) million (Eliasson 2009).

Congestion pricing is gaining limited, momentum in the United States, with federal funding for pilot schemes under the Value Pricing Program and the reduction of regulatory obstacles to freeway pricing. One type of scheme involves opening up links previously reserved for high-occupancy vehicles to single-occupant vehicles in exchange for a fee, for example on I-15 in San Diego. Another is using tolls to fund new infrastructure, such as the lanes opened on SR-91 in Orange County California in 1995. 
Under any congestion-pricing scheme, the toll should rise and fall progressively during course of the rush hour to encourage people to depart before, or after, the peak hour and thereby "flatten" the pattern of trip time departures. The toll should also vary with driving direction, that is, tolls for drivers with reverse commutes should be lower (e.g., Santos, 2004b). And the effectiveness of pricing schemes can and often should be enhanced with complementary measures, such as better transit options, provision of bike routes, and incentives for employers to offer flexible work hours and to re-locate away from the downtown areas.

\section{E. Vehicle Ownership Taxes}

At present, as summarized in Table 5, Mauritius imposes three taxes on vehicle ownership, all related to engine size, as measured by cylinder capacity in cubic centimeters (cc). There is a one-off excise duty on the car price of 55 percent if the engine capacity is less than 1,600 cc or 100 percent if the engine capacity is greater than 1,600 cc (although some people, like civil servants and agricultural users, are exempt from these excises). There is also a one-off registration fee for imported vehicles of between Rs 12,500 and Rs 150,000 (US\$416-5,000) depending on engine size. Registration fees are paid again (at lower rates, depending on vintage) if vehicles are subsequently sold. And there is an annual road tax of between Rs 3,500 and Rs 13,000, again depending on engine size.

Table 5. Vehicle Ownership Taxes, 2009

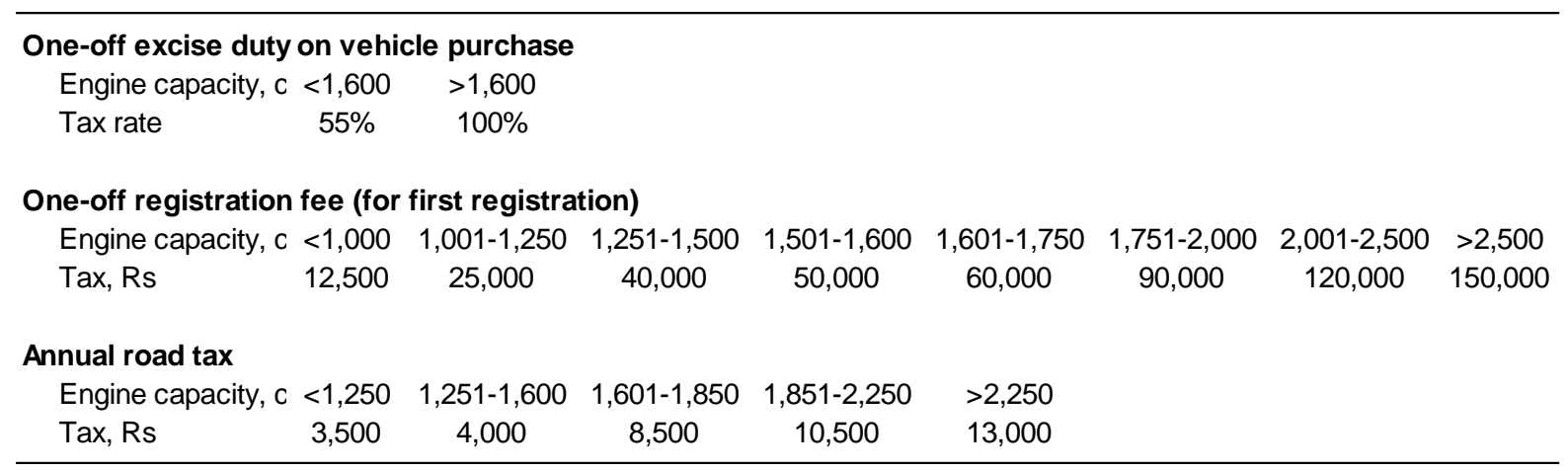

Source: Mauritius, National Transport Authority (2010).

In this section, we first discuss various problems with the current tax system, and evaluate various reform options including graduated taxes on new-vehicle $\mathrm{CO}_{2}$ per kilometer, a simple tax on $\mathrm{CO}_{2}$ per kilometer, "feebates", and a mileage toll.

Deficiencies in the current tax system. There are several deficiencies in this tax system. First, it provides only weak incentives to reduce vehicle miles driven. Not only does this fail to fully exploit a useful avenue for reducing $\mathrm{CO}_{2}$ emissions but, more importantly, it has only limited effects on reducing traffic congestion, the most important transportation externality. By making vehicles more costly to own, all the current taxes reduce the overall demand for 
vehicles. However, they do not provide an incentive to reduce the amount a given vehicle is driven. In this regard, vehicle taxes exploit perhaps only about a third of the reduction in driving that would be forthcoming under equivalently scaled taxes on fuel or vehicle miles. ${ }^{25}$

Second, the tax system also provides only weak incentives to improve fuel economy, or reduce $\mathrm{CO}_{2}$ per kilometer. One reason is that it does not reward a switch towards more fuel efficient vehicles within an engine size category defined by a given tax rate. Another is that smaller engine size by itself does not always imply greater fuel economy. But most important, the tax system does not encourage purchase of vehicles with other attributes that improve fuel economy such as lighter materials, fuel injection, reduced rolling resistance, smaller cabin size, and better aerodynamics. ${ }^{26}$

Third, because people pay most of the tax only at the moment they buy a new car, the tax system can slow fleet turnover. Thus, people may hold onto older, more polluting vehicles longer.

Fourth, the tax system is complicated, making it difficult for consumers to understand the full tax implications (over the vehicle life) of their decisions, for example, the tax savings from buying a vehicle with better fuel economy.

Finally, returning to the first point, it is not immediately clear that ownership taxes should be encouraging reductions in $\mathrm{CO}_{2}$ per kilometer. Fuel taxes already provide ongoing incentives for fuel economy improvements and additional incentives violate the principle of uniformly pricing $\mathrm{CO}_{2}$ across all sectors. ${ }^{27} \mathrm{We}$ leave this issue aside however, and take as given that policymakers wish to use vehicle ownership taxes to further reduce $\mathrm{CO}_{2}$ per kilometer in a cost-effective way, while meeting revenue and equity objectives.

Graduated taxes on $\mathrm{CO}_{2}$ per kilometer. One possibility for reform would be to follow France and other European countries and levy excise taxes on certified $\mathrm{CO}_{2}$ per kilometer for cars, where the tax rate as a percentage of the CIF (cost, insurance, and freight) value starts at a low or zero rate and increases in steps with higher $\mathrm{CO}_{2}$ per kilometer. The advantage of basing vehicle taxes on $\mathrm{CO}_{2}$ per kilometer rather than engine size is that it would promote a

\footnotetext{
${ }^{25}$ In the United States, about a third of the estimated reduction in driving in response to higher per mile costs comes from reduced overall vehicle demand and about two-thirds comes from reduced miles per vehicle use (e.g., Fischer and others, 2007).

${ }^{26}$ For a detailed discussion of technological possibilities for improving fuel economy, see the National Research Council (2002).

${ }^{27}$ The loss of cost-effectiveness may not be that great, however, if $\mathrm{CO}_{2}$ is only moderately responsive to pricing in other sectors.
} 
broader range of possibilities for improving fuel economy, thereby helping to address the second deficiency noted above. This tax system does not address further concerns, however.

First, it violates the principle of taxing $\mathrm{CO}_{2}$ emissions at the same rate, regardless of their source. Under a system of graduated taxes on $\mathrm{CO}_{2}$ per kilometer, too much of the burden of emissions reductions is likely placed on shifting people into small vehicles and too little from people purchasing more fuel-efficient versions of existing (small, medium, and large) vehicles. In contrast, taxing all $\mathrm{CO}_{2}$ emissions at the same rate would promote cost effectiveness because each of the many possibilities for reducing emissions will be pursued until the cost of an additional ton of reductions is equated with the $\mathrm{CO}_{2}$ tax.

Second, the tax system does not provide incentives for people to drive their vehicles less. In fact, evidence suggests that people drive their vehicles more when the vehicle fuel economy is greater (i.e., when fuel costs per kilometer are smaller) ${ }^{28} \mathrm{~A}$ better approach would be to achieve some of the $\mathrm{CO}_{2}$ reduction through reduced driving (and gain the congestion benefit) and correspondingly less through higher fuel economy.

Third, the proposed tax system would still be complicated. People would have to combine three different tax schedules to assess the tax savings (over the course of a vehicle's life) from choosing among vehicles with different engine sizes and $\mathrm{CO}_{2}$ per kilometer.

Fourth, revenues may decline substantially - an important concern for Mauritius. There is a fundamental tension between effectiveness and revenue under graduated $\mathrm{CO}_{2}$ per kilometer taxes: the more effective the policy, in terms of shifting people into low $\mathrm{CO}_{2}$ per kilometer vehicles, the less revenue it raises, because these are vehicles with low or zero tax rates. This is particularly important over times unless the graduated taxes are adjusted in line with the behavioral response.

Tax on $\mathrm{CO}_{2}$ per kilometer. An alternative approach would be a proportional tax on $\mathrm{CO}_{2}$ emissions per kilometer. This policy would promote cost-effectiveness by providing the same reward for the last ton of $\mathrm{CO}_{2}$ reduced, whether it comes from improving the fuel economy of existing small vehicles, medium vehicles, or large vehicles, or from people switching from large to medium vehicles, and from medium to small vehicles. Moreover, the tax provides ongoing incentives to always keep reducing $\mathrm{CO}_{2}$ per kilometer, even in vehicles that are already relatively fuel efficient.

The drawback of this option is that it changes the progressivity (or fairness) of the tax system, which is major concern to policymakers. Currently, the excise tax system in

\footnotetext{
${ }^{28}$ A widely cited study for the United States by Small and Van Dender (2006) estimates that roughly 10 percent of fuel savings from improvements in fuel economy are offset by people driving more.
} 
Mauritius is proportional to purchase price for the majority of vehicles, that is, those with engine size below 1,600 cc, and then sharply higher for vehicles with larger engines. However, given that, loosely speaking, $\mathrm{CO}_{2}$ per kilometer tends to increase by less than in proportion to vehicle price, switching to a pure tax on $\mathrm{CO}_{2}$ per kilometer will imply that taxes are typically smaller as a percentage of price for more expensive vehicles.

Feebate. Another alternative would be to encourage fuel economy improvements through a (revenue-neutral) feebate, and maintain revenues through an excise tax on vehicle price.

A feebate imposes a proportional fee on $\mathrm{CO}_{2}$ per kilometer over and above some threshold or "pivot point" level for relatively fuel-inefficient vehicles and a proportional rebate or subsidy on the difference between $\mathrm{CO}_{2}$ per kilometer and the pivot point level for relatively fuel efficient vehicles. That is, a vehicle incurs a fee or rebate according to the simple formula $t \cdot\left(\mathrm{CO}_{2} / \mathrm{km}-\overline{\mathrm{CO}_{2} / \mathrm{km}}\right)$, where the bar denotes the pivot point and $t$ is the tax rate per gram of $\mathrm{CO}_{2} /$ kilometer. $^{29}$

To attain approximate revenue neutrality, $\overline{\mathrm{CO}_{2} / \mathrm{km}}$ could be defined by the expected average rate across vehicle purchases and can be reduced as average $\mathrm{CO}_{2}$ per kilometer declines for new vehicles over time. Choosing a higher value for $t$ implies stronger incentives to adopt more fuel efficient variants of existing models and to shift away from large to small vehicles. It is easily adjusted over time, for example, it can be ramped up if hoped for emissions reductions (or fuel economy improvements) do not materialize.

Revenues can be maintained by applying a uniform (or somewhat graduated) percentage tax to the purchase price of all vehicles. This avoids the problem of revenue loss as people choose more efficient vehicles in response to the feebate incentive, since they still pay the same excise tax rate. (Potential revenue losses from the feebate component are avoided, because the pivot point declines over time as the average $\mathrm{CO}_{2}$ per kilometer of the new vehicle fleet falls).

Comparing the progressivity of alternative tax systems. Table 6 illustrates the overall progressivity of alternative tax systems, using a database of all (new and used) vehicle purchases for Mauritius for $2010 .{ }^{30}$ Vehicles are grouped by $\mathrm{CO}_{2}$ per kilometer, though the

\footnotetext{
${ }^{29}$ For more detail on how feebates work, see Small (2010). There is growing interest in feebates among policymakers (e.g., Greene et al. 2005, Fischer 2008). They have been discussed as an alternative to fuel economy regulations in the United States since the early 1990s. Worldwide, regulators have implemented modest feebates for consumers in Ontario in 1991, federal Canada in 2007, and France in 2008.

${ }^{30}$ The database contains information on $\mathrm{CO}_{2}$ per kilometer, purchase price, and taxes paid, for each vehicle. I am grateful to Mahen Bheekhee of the Ministry of Finance in Mauritius for providing the data. In practice (as indicated by this database) taxes are not paid on about 25 percent of vehicle purchases because of exemptions for civil servants. If these exemptions are maintained, the average tax collected per vehicle purchase in the bottom row of Table 5 would be about 25 percent lower. Scaling back these exemptions would make sense on
} 
average pre-tax vehicle price rises steadily with higher $\mathrm{CO}_{2}$ per kilometer. Here we simplify by comparing policies assuming the same pattern of vehicle sales as in 2010 (allowing for behavioral responses would moderately affect the computed tax rates necessary to maintain revenues).

Table 6. Alternative Vehicle Tax Systems, 2010

\begin{tabular}{|c|c|c|c|c|c|c|}
\hline \multirow[b]{2}{*}{$\begin{array}{l}\text { Vehicle Type } \\
\text { grams } \mathrm{CO}_{2} / \mathrm{km}\end{array}$} & \multirow[b]{2}{*}{$\begin{array}{c}\text { Purchases } \\
\text { in } 2010\end{array}$} & \multirow[b]{2}{*}{$\begin{array}{c}\text { Average Pre- } \\
\text { Tax Purchase } \\
\text { Price, Rs }\end{array}$} & \multicolumn{4}{|c|}{ Tax Paid, Rs } \\
\hline & & & Current & $\begin{array}{c}\text { Proportional } \\
\text { Tax on } \mathrm{CO}_{2} \\
\end{array}$ & $\begin{array}{c}\text { Proportional } \\
\text { Excise Tax, 66\% }\end{array}$ & $\begin{array}{c}\text { Feebate and } \\
\text { Proportional } \\
\text { Excise Tax, 66\% }\end{array}$ \\
\hline $96-115$ & 920 & 202,156 & 100,759 & 179,350 & 133,423 & 65,791 \\
\hline $116-125$ & 946 & 284,412 & 154,055 & 204,850 & 187,712 & 144,269 \\
\hline $126-155$ & 4,964 & 314,708 & 182,472 & 238,850 & 207,707 & 200,035 \\
\hline $156-160$ & 411 & 431,987 & 243,400 & 268,600 & 285,111 & 301,904 \\
\hline 161-195 & 1,489 & 478,472 & 334,999 & 302,600 & 315,792 & 359,246 \\
\hline $196-245$ & 448 & 908,294 & 902,692 & 374,850 & 599,474 & 718,463 \\
\hline$>245$ & 73 & $1,572,146$ & $1,571,342$ & 442,000 & $1,037,616$ & $1,241,196$ \\
\hline Total/Average & 9,251 & 370,654 & 244,535 & 249,228 & 249,228 & 244,456 \\
\hline
\end{tabular}

Source: Author's calculations using a customs database on all imported vehicle purchases.

1/ Calculations ignore exemption provisions (e.g., for civil servants). Projections do not take into account the impact of different tax systems on shifting vehicle sales.

The current excise tax system is progressive in the sense that the average rate of tax rises with the vehicle purchase price, from 50 percent for the lowest price vehicles (which are all less than $1,600 \mathrm{cc}$ ) to 100 percent for the highest-price vehicles (which are all 1,600 cc or larger).

Under a proportional tax on $\mathrm{CO}_{2}$ per kilometer, maintaining the same (approximate) average revenue for a vehicle purchase would require a tax rate of $\mathrm{Rs} 1,700$ per grams of $\mathrm{CO}_{2}$ per kilometer ${ }^{31}$ Here the tax system is highly regressive. The average tax paid per vehicle falls from 89 percent for the lowest-price vehicles to just 28 percent for the most expensive.

economic efficiency grounds, and would allow a lowering of excise tax rates, for the same revenue total collected by the government.

${ }^{31}$ This tax rate is broadly consistent with incentives for reducing $\mathrm{CO}_{2}$ per kilometer under vehicle excise tax systems in the lower portion of the distribution of vehicles (ordered) by $\mathrm{CO}_{2}$ per kilometer in, for example, the United Kingdom (author's calculations based on annual vehicle excises given in www.ifs.org.uk/fiscalFacts/taxTables). But the implicit prices on $\mathrm{CO}_{2}$ are extremely large. Assuming the average car is driven 10,000 kilometers a year for 15 years, the implicit $\mathrm{CO}_{2}$ price is $\mathrm{Rs} 11,333$ per ton. 
We also illustrate a case with a feebate set at the same rate ( $\mathrm{Rs} 1,700$ per gram $\mathrm{CO}_{2}$ per kilometer) as in the previous case, with a pivot point of 147 grams of $\mathrm{CO}_{2}$ per kilometer (equal to the average emission rate) to make the feebate component revenue-neutral. The feebate is combined with a proportional excise tax of 66 percent which (approximately) maintains average revenue overall per vehicle. The feebate component itself reflects the difference in tax payments between last column in Table 6 (the feebate-excise tax combination) and the second-to-last column (the excise tax component only).

Overall, the feebate-excise tax combination is progressive, with tax rates rising from 33 percent for low-price vehicles to 79 percent for high-price vehicles; compared with the existing system, tax rates are lower for the two lowest-price vehicle categories, and for the two highest-price categories, and somewhat higher for the middle three categories. (This system could be made more progressive over the middle to top-end through a graduated excise tax system).

Transitioning to mileage tolls. None of the above tax systems do anything to reduce miles driven per vehicle. How might the current tax system be gradually transformed into the kind of nationwide, GPS-based tolling system that offers the best hope to controlling traffic congestion, the most important externality?

One possible starting point would be to turn the road tax into a variable charge. That is, the annual road tax payment would be the product of a "congestion charge" per kilometer and total kilometers driven by the motorist in the previous year. Motorists are therefore encouraged to drive less to reduce next year's tax bill.

Annual kilometer driven can be recorded by yearly odometer readings - for example, when cars are brought in for safety inspections (readings would also be taken when used vehicles are sold). ${ }^{32}$ At the same time, a progressive transition to GPS-based charging system could be encouraged through offering lower toll rates to drivers who can demonstrate (by installing GPS) that their driving is predominantly rural or off-peak. As more drivers opt for GPS, the congestion toll for drivers on the odometer system could rise, encouraging further switching to GPS. Again, the tax rate could easily be chosen to maintain approximate revenue from the road tax (by setting the per kilometer charge equal to total road tax revenue last year divided by projected total car mileage under the new scheme).

\footnotetext{
${ }^{32}$ This may create an incentive to tamper with odometers. However, tampering is difficult (at least by amateurs) without leaving traces and there could be stiff fines for those who are caught driving without a functioning odometer. And fraud will become more difficult once a history of odometer readings has been built up for different drivers (an unusually low recorded mileage, relative to others or one's prior driving record, would arouse suspicion).
} 
Insurance reform. Another (complementary) way to further reduce vehicle use is to encourage, through tax incentives, a progressive shift towards Pay-As-You-Drive (PAYD) automobile insurance (Bordhoff and Noel, 2008). Currently, auto insurance takes the form of a fixed payment, which is only weakly related to kilometer driven. Under PAYD, the insurance payment equals a fee per kilometer, times annual kilometer driven: if someone drives 20,000 kilometers in a year rather than 10,000 kilometers, they would pay twice as much in insurance.

An attractive feature of insurance reform is that it can discourage driving without imposing a new tax burden on motorists. This is because the increase in the per-kilometer cost of driving is offset by the corresponding reduction in annual premiums; the average motorist could still choose to drive the same amount as before the insurance reform and be no worse off. In fact, many motorists - at least those with lower-than-average mileage — would end up paying less in driving costs under PAYD than they currently do.

PAYD can be voluntary and introduced gradually over time as people gain familiarity with the idea of kilometer-based insurance. Insurance companies can market PAYD insurance alongside their conventional insurance plans. Drivers with low annual mileage have an incentive to opt for per kilometer insurance because it would reduce their annual premium payments. Under the present system, both low- and high-mileage drivers pay approximately the same annual premiums, even though the former are less likely to crash and make claims on insurance companies. As low-mileage drivers begin to opt out of lump-sum insurance, over time this would increase rates for the remaining drivers, in turn providing them with more incentive to switch to mileage-based insurance.

Insurance companies could meter a vehicle owner's mileage through periodic odometer inspections. The per mile charges would be scaled by the driver's rating factor, as determined by the insurance company based, for example, on age and prior crash record (rating factors may also depend on vehicle characteristics). An added advantage of PAYD, therefore, is that it encourages people with highest crash risk to reduce driving the most. ${ }^{33}$

Further green tax possibilities. As the population of Mauritius expands, disposing of household waste becomes more challenging, with growing pressure on landfill capacity and increased risk posed by leakage of hazardous waste. Tax incentives can be provided to encourage households to economize on waste, increase the portion of waste that is recycled, and separate hazardous or toxic wastes.

\footnotetext{
${ }^{33}$ PAYD schemes have emerged in several regions of the United States, partly in response to policy incentives. For example, in Oregon, insurance companies were offered a one-off tax credit of US\$100 (Rs 3,000) for each motorist that signed up for PAYD. The same tax incentive might be reasonable for Mauritius. If, in response, 2 percent of motorists made the switch to PAYD each year, the annual revenue loss to the government would be modest at around Rs 15 million.
} 
One option is pay-by-the-bag schemes, which cover about 25 percent of households in the United States (e.g., Fullerton 2005). If households had to pay for their waste, this would encourage them to generate less waste by, for example, increased composting, reduced consumption of packaged products and separation of recyclables (newspapers, glass, aluminum cans, etc.). Ideally, households would be given separate bins for recycling, which would be collected at the curbside, free of charge. The potential drawback of pay-by-the-bag however, is that it can encourage illegal dumping of trash, especially in rural areas. Pay-by-the-bag is recommended only in cases where illegal dumping can be successfully deterred through, for example, a stiff penalty system.

To lower environmental risks, hazardous items like batteries, tires, and used electronic equipment should be disposed of safely, rather than deposited in landfills with other trash. These hazardous products are potentially good candidates for deposit-refund systems. For example, a portion of the existing tax on tires and batteries could be rebated to individuals when they return these items to special collection centers.

Taxes could also play a useful role in managing off-shore fisheries in cases where depletion is a potential problem. Left to their own devices, individual fishermen tend to catch too much fish from society's perspective, as they do not consider the impact of depletion on reducing the availability of fish stocks for future generations. Market-based policy approaches that effectively charge fishermen for extracting fish (as pioneered in New Zealand) have proved effective in addressing overfishing. This approach is far better than other approaches, like restrictions on gear or harvest season, which do not address the potential problem of excessive incentives to catch as much as quickly as possible.

Scaling back the large subsidy for LPG (used in domestic cooking and water heating) would also make economic and environmental sense as, for example, it disadvantages clean solar water heaters. Moreover, it would remove the contradiction in the tax system that taxes LPG under the MID levy but subsidizes LPG at the same time, making the MID levy ineffective. Targeted packages to compensate low-income groups for higher LPG prices would be needed, however.

As regards water issues, tariffs in Mauritius are set to recover operating costs, but not the cost of investments and upgrades to the water supply system. Water rationing remains a problem, with supply available only at restricted times of the day, especially during drought periods. An increase in water tariffs, especially during times of water scarcity, would help to better align the demand for water with available supply, by encouraging households and industry to conserve on water use. More important, higher tariffs could help to fund needed capacity improvements in the water supply system, particularly replacement of old, leaky pipes in urban areas and construction of new dams to enhance water supply. A competitive bidding process could be offered for these investments, with contracts allowing private companies to recover large upfront investment costs through tariffs over a sustained period of time. 
A number of European countries have taxed stationary source emissions of sulfur dioxide $\left(\mathrm{SO}_{2}\right)$ and oxides of nitrogen $\left(\mathrm{NO}_{\mathrm{x}}\right)$, while in the United States the cap-and-trade program to reduce $\mathrm{SO}_{2}$ is widely acclaimed as an environmental success story. In fact, the estimated human health benefits from reducing $\mathrm{SO}_{2}$ in the United States are huge relative to the costs of abating this pollutant through, for example, post-combustion scrubbing technologies (e.g., National Research Council 2009). For Mauritius, however, imposing a tax on power plant emissions of $\mathrm{SO}_{2}$ does not appear to be worthwhile. These emissions are already subject to performance standards at the local power plants. More important, $\mathrm{SO}_{2}$ emissions in Mauritius become quickly dispersed (unlike vehicle emissions), given wind patterns and the coastal location of power plants.

\section{Conclusion}

There is ample scope worldwide for reforming fiscal systems to better address major externality problems including local air quality, road congestion, and climate change. This paper attempts to provide a template for thinking through some possible directions for tax reform, using Mauritius as a case study, and focusing mainly on the taxation of fuels and motor vehicles. In some cases, economically efficient tax reforms could be straightforward to implement, such as incorporating carbon content into the taxation of fossil fuels. For other problems, such as vehicle fuel economy, tax design is more complicated if governments care about revenue as well as environmental objectives - the cost-effective solution in this case may involve two separate tax instruments, one for each objective. In still other cases, such as nationwide congestion pricing, efficient policies would require far more novel tax reforms that have yet to be widely implemented in any country. But even here, a first step in the right direction would, in principle, be straightforward to implement by converting the existing road tax from a lump-sum fee into a per-kilometer charge, and coupling this with further incentives for motorists to voluntarily switch to GPS-based metering. Providing tax incentives for pay-as-you-drive auto insurance could, at the same time, reinforce the effects of this tax change, while also helping to familiarize drivers with the concept of variable charges for vehicle use. 


\section{Appendix. Some Details on Calculations Underlying Section III}

Local Pollution Damages. We start with a value of US\$0.006 per kilometer from the U.S. literature (see above), and then make two adjustments to extrapolate this figure to Mauritius.

First, we adjust for differences in the value of a statistical life (VSL), where the VSL reflects people's willingness to pay for mortality risk reductions expressed per fatality avoided. The VSL is used to quantify mortality effects, which is by far and away the largest component of damages from the U.S. studies. To extrapolate the U.S. VSL to Mauritius, we employ the commonly used formula (e.g., Cifuentes and others, 2005, pp. 40-41):

$$
\text { (1) } V S L_{M}=V S L_{U S} \cdot\left(\frac{I_{M}}{I_{U S}}\right)^{\eta_{U S L}}
$$

where $I_{M}$ and $I_{U S}$ denote real per capita income in Mauritius and in the United States, respectively. $\eta_{V S L}$ is the elasticity of the VSL with respect to income (i.e., the percent increase in the VSL in response to a 1 percent increase in real income). From World Bank (2009) we assume $I_{M} / I_{U S}$ is (US $\left.\$ 12,480 / \$ 46,970=\right)$ ) 0.266 , based on PPP exchange rates.

The appropriate value for $\eta_{V S L}$ is unsettled at present. A widely cited study by Viscusi and Aldy (2003) suggests a value of around 0.5 , which is consistent with the views of Alan Krupnick, a leading expert on the issue. ${ }^{34}$ On the other hand, Hammitt and Robinson (2011) argue for using a value of unity, or even higher. Here we take a compromise and use a value of 0.75 .

Using (1) and the above data, the VSL for Mauritius is 37 percent of that for the US. We assume the U.S. VSL is Rs 108 million (US\$6 million), based on the National Research Council (2009) and current practice by the U.S. Environmental Protection Agency and converting using the PPP rate (Rs 18 per US\$1). Thus we obtain a VSL for Mauritius of Rs 40 million (US $\$ 2.2$ million).

Second, we make a crude adjustment for differences in emission rates. Given lack of data on the in-use vehicle fleet, we hazard the guess that emission rates per kilometer are twice as high in Mauritius as in the United States, due to the older vehicle fleet and lower portion of cars initially subject to emissions standards, which were recently aggressively tightened across the major vehicle manufacturing countries.

Multiplying the U.S. figure by the ratio of VSLs and then doubling it gives approximately Rs 0.08 per kilometer.

\footnotetext{
${ }^{34}$ Personal communication, January 2011. Krupnick has been involved in a number of stated preference studies applying a common methodology for eliciting the VSL across countries with very different income levels.
} 
Marginal costs of congestion. The marginal cost of traffic congestion depends on the marginal delay, or the increase in travel time to other road users, due to the added congestion caused by additional driving by one vehicle. Marginal costs also depend on how people value the increase in travel time.

To obtain marginal delay for Port Louis, we start with an estimate of the average delay caused by congestion. This can be inferred from comparing observed travels speeds with speed under free-flow conditions. Based on a (slightly dated and therefore conservative) assessment of congestion in Port Louis by Menon (2004), we assume that travel speeds at peak period are 10 kilometers per hour and free-flow speeds (with no congestion) would be 25 kilometers per hour. Inverting these speeds, we can infer that on average the extra travel time per kilometer due to congestion at peak period in Port Louis is 3.6 minutes ( 0.06 hours), which is likely to be an underestimate. Assuming traffic is essentially free-flowing in the off-peak period (weekends and non-rush hours during weekdays when commuters are not on the roads) and that vehicle mileage is equally distributed across peak and off-peak periods, the delay averaged over all driving in Port Louis is 1.8 minutes ( 0.03 hours) per kilometer. ${ }^{35}$

An extra vehicle on a road slows travel speeds by more on a road that is already congested (where there is less room on the road for the vehicle) compared with a road that is relatively free flowing. Moreover, the added delay imposed on others increases with a greater number of vehicles on the road. For these reasons, the marginal delay rises with more traffic on the road. From Small (1992, pp. 70-71), we assume that marginal delay is four times the average delay, or 7.2 minutes ( 0.12 hours) per kilometer. ${ }^{36}$

We were unable to obtain a breakdown of vehicle miles travelled by urban/rural region. We hazard the guess that 25 percent of driving occurs in Port Louis, 40 percent in other urban areas, and 35 percent in rural areas. Furthermore, we assume that marginal delays in other cities are one-third of those for the (highly congested) capital, and zero for rural areas (this follows estimates in Parry and Strand, 2010, for Chile). Weighting marginal delays in different regions by their shares in nationwide mileage, we therefore obtain marginal delays averaged across the country of 2.6 minutes (0.044 hours) per kilometer. Although this calculation may appear very ad hoc, alternative plausible assumptions about mileage shares

\footnotetext{
${ }^{35}$ Roughly speaking, from Menon (2004, Tables 4 and 5), we infer that 50 percent of weekly traffic occurs during the peak weekday period of 7-10 a.m. and 4-7 p.m. The same is broadly true, for example, of Santiago in Chile (e.g., Parry and Strand, 2010).

${ }^{36}$ This is based, approximately, on reported estimates of the marginal to average delay ratio for congested urban areas. Estimates of the ratio of marginal to average delay typically vary between about 2.5 and 5.0. A value of 4 is implied by the Bureau of Public Roads formula, which is widely used in traffic engineering models. See, for example, Lindsey and Verhoef (2000) for further discussion.
} 
and relative marginal delays across regions have a relatively modest effect on our (ballpark) figure.

According to economic theory, people supply work effort up to the point where their benefit from additional work effort - the net of tax wage per hour-equals the value of the time they forgo in other activities, such as leisure time or work in the informal sector (e.g., Becker, 1965). If people value the pure disutility from an extra hour of work and an extra hour of travel time equally, then the value of travel time (VOT) should approximately reflect the net-of-tax wage. More generally, travel might be valued at less than the net wage if, for example, people prefer to be in a car rather than at work, or vice versa if they prefer the work environment to being in a car.

Most reviews of the empirical literature suggest a VOT for personal auto travel equal to about half the market wage (e.g., Waters 1996; DOT, 1997; and Mackie and others, 2003). Making a standard assumption for the U.S. that the VOT equals half the market wage for urban areas implies a U.S. VOT of about $\$ 10$ per hour. ${ }^{37}$ To extrapolate the VOT to Mauritius, using an analogous expression to that in equation (1), we multiply by the ratio of per capita income in Mauritius to that in the United States (0.266), where this ratio is raised to the power of the VOT/income elasticity. Estimates of this elasticity for high-income countries are typically around unity (e.g., Wardman 2001; Mackie and others, 2003). Although it is not clear that this estimate would still be valid for lower income countries like Mauritius, in the absence of evidence to the contrary, we assume the elasticity is unity. This implies a VOT for Mauritius of US\$2.7 or Rs 49 per hour.

Multiplying marginal delays by the VOT gives marginal congestion costs of approximately Rs 2.1 per kilometer for the nation as a whole. For Port Louis, our estimated marginal congestion costs are approximately Rs 12 and 6 per kilometer for peak driving, and averaged over time of day, respectively.

Marginal external cost of traffic accidents. Assessing to what extent policies are warranted to reduce the incidence of road accidents is tricky. While some accident risks (e.g., injury to pedestrians), may not be taken into account by individual drivers, other risks (e.g., injury risks to drivers in single-vehicle collisions) might be. Here we mainly focus on mortality risk given that, for lower and middle income countries, this appears to be the largest determinant of accident externalities (e.g., Parry and Strand, 2010).

According to the Mauritius CSO (2010a, Table 2.20), there were 140 road deaths in Mauritius in 2009, of which 54 were pedestrian deaths and another 16 were pedal cyclist deaths. We make the common assumption that all pedestrian and pedal cyclist deaths are

\footnotetext{
${ }^{37}$ The gross urban wage is taken from the U.S. Bureau of Labor Statistics (2006, Table 1).
} 
external. Of the deaths to vehicle occupants and autocycles/motorbikes, many of these are in single vehicle accidents, and represent internalized risks. To what extent injuries in multi-vehicle collisions represent external costs, as opposed to costs taken into account by individual drivers, is unsettled. All else constant, the presence of an extra vehicle on the road raises the likelihood that other vehicles will be involved in a collision, but a given collision will be less severe if people drive slower or more carefully in heavier traffic. We therefore do not count these deaths as external.

External fatalities (70) are valued using the VSL (Rs 40 million). We therefore obtain a total external cost of Rs 2,800 million.

There are various other dimensions to external accident costs, such as non-fatal injuries, third-party property damage, and traffic hold-ups. Due, in part, to a lack of local data needed to quantify these other costs we simply assume they are the same in size, relative to the external costs from fatality risk, as estimated for by Parry and Strand (2010) for Chile, about 15 percent. Thus, we obtain total external costs of Rs 3,220 million. Dividing by total vehicle kilometer travelled by all vehicles (4,050 million) gives an average external cost (across all vehicles) of Rs 0.8 per mile.

Optimal Fuel Tax Assessment. Parry and Strand (2010) discuss a conceptual framework (based on prior literature) for estimating optimal fuel taxes. The main complication is that externalities that vary with kilometers driven, rather than fuel use, need to be scaled back because a large portion of the tax-induced reduction in fuel comes from improvements in fuel economy (which do not affect these externalities). In fact, if all of the reduction in fuel use came from increased fuel economy and none from reduced driving, there would be no impact on mileage-related externalities. For Chile, 40 percent of any tax-induced reduction in fuel use comes from reduced driving (Parry and Strand, 2010). Given that vehicle ownership taxes in Mauritius already create significant incentives for higher fuel economy, we assume 50 percent of the gasoline demand elasticity reflects reductions in driving, hence we scale back mileage-related external costs by 50 percent in computing optimal fuel taxes.

Mileage-related externalities include congestion and accidents. But they also include local pollution, given that vehicles are initially subject to uniform emissions per mile standards (that is, buying a fuel efficient vehicle does not reduce emissions, if all vehicles, regardless of their fuel economy, meet the same emissions standard).

One further complication is that driving on congested roads (which is dominated by commuters) tends to be less sensitive to higher fuel prices than rural or off-peak driving. This reduces congestion benefits from fuel taxes as a disproportionately large amount of the reduction in driving occurs on uncongested roads. Following Parry and Strand (2010), we scale back congestion benefits by one-third to make some allowance for this. 
All externalities are converted from a per kilometer basis to a per liter basis by multiplying by fuel economy (13 kilometer per liter). ${ }^{38}$ Thus, using external costs discussed above, the optimal gasoline tax is computed by $13 \times(0.06+0.5 \times(0.08+2.1 \times 0.67+0.8))$, which gives Rs 15.6 per liter.

\footnotetext{
${ }^{38}$ We ignore the slight complication posed by the effect of higher fuel taxes on increasing fuel economy.
} 


\section{REFERENCES}

Allcott, Hunt and Nathan Wozny, 2009, "Gasoline Prices, Fuel Economy, and the Energy Paradox," Discussion Paper (Cambridge: Massachusetts Institute of Technology, Department of Economics).

Becker, Gary S., 1965, “A Theory of the Allocation of Time,” Economic Journal, Vol. 75, No. 299, pp. 493-517.

Bovenberg, A. Lans, and Lawrence H. Goulder, 2002, "Environmental Taxation and Regulation," in Handbook of Public Economics, ed. by A. Auerbach and M. Feldstein (New York: North Holland).

Bordhoff, Jason E. and Pascal J. Noel, 2008, "Pay-as-You-Drive Auto Insurance: A Simple Way to Reduce Driving-Relayed Harms and Increase Equity," Discussion Paper 08-09 (Washington: Brookings Institution, the Hamilton Project).

Cifuentes, Luis A., Alan J. Krupnick, Raúl O’Ryan and Michael Toman, 2005, “Urban Air Quality and Human Health in Latin America and the Caribbean," Working Paper (Washington: Inter-American Development Bank).

Clarke, Leon, Jae Edmonds, Volker Krey, Richard Richels, Steven Rose, and Massimo Tavoni, 2009, "International Climate Policy Architectures: Overview of the EMF 22 International Scenarios," Energy Economics, Vol. 31, Supplement 2, pp. S64-S81.

Davis, Lucas W., 2008, "The Effect of Driving Restrictions on Air Quality in Mexico City," Journal of Political Economy, Vol. 116, No. 1, pp. 38-61.

Dockery, Douglas W., C. Arden Pope, Xiping Xu, John D. Spengler, James H. Ware, Martha E. Fay, Benjamin G. Ferris, and Frank E. Speize, 1993, “An Association Between Air Pollution and Mortality in Six U.S. Cities," New England Journal of Medicine, Vol. 329, No. 24, pp. 1753-59.

Downs, Anthony, 1992, Stuck in Traffic: Coping with Peak-Hour Traffic Congestion, (Washington: Brookings Institution Press).

Eliasson, Jonas, 2009, “A Cost-Benefit Analysis of the Stockholm Congestion Charging System," Transportation Research Part A: Policy and Practice, Vol. 43, No. 4, pp. 468-80. 
Ellerman, A. Denny, and Paul L. Joskow, 2008, “The European Union's Emissions Trading System in Perspective" (Arlington: Pew Center for Global Climate Change).

Eskeland, Gunnar, S., 1994, "A Presumptive Pigovian Tax: Complementing Regulation to Mimic an Emissions Fee,” World Bank Economic Review, Vol. 8, No. 3, pp. 373-94.

Fischer, Carolyn, 2008, "Comparing Flexibility Mechanisms for Fuel Economy Standards," Energy Policy, Vol. 36, No. 8, pp. 3116-24.

Fischer, Carolyn, Winston Harrington, and Ian W.H. Parry, 2007, "Should Corporate Average Fuel Economy (CAFE) Standards be Tightened?” Energy Journal, Vol. 28, No. 4, pp. 1-29.

Fullerton, Donald, 2005, “An Excise Tax on Solid Waste?" in Theory and Practice of Excise Taxation: Smoking, Drinking, Gambling, Polluting and Driving, ed. by S. Cnossen, (Oxford: Oxford University Press).

Greene, David L., Philip D. Patterson, Margaret Singh, and Jia Li, 2005, "Feebates, Rebates and Gas-Guzzler Taxes: A Study of Incentives for Increased Fuel Economy," Energy Policy, Vol. 33, No. 6, pp. 757-75.

Gurjara, B.R., T.M. Butlerb, M.G. Lawrence, J. Lelieveld, 2008, "Evaluation of Emissions and Air Quality in Megacities," Atmospheric Environment, Vol. 42, No. 7, pp. 15931606.

Hammitt, James K., and Lisa A. Robinson, 2011, “The Income Elasticity of the Value per Statistical Life: Transferring Estimates between High and Low Income Populations," Journal of Benefit-Cost Analysis, Vol. 2, No. 1, Article 1.

Hausman, Jerry A., 1979, "Individual Discount Rates and the Purchase and Utilization of Energy-Using Durables,” Bell Journal of Economics, Vol. 10, No. 1, pp. 33-54.

Intergovernmental Panel on Climate Change, 2007, Climate Change 2007: The Physical Science Basis, Contribution of Working Group I to the Fourth Assessment Report of the IPCC, (Cambridge: Cambridge University Press).

International Association of Public Transport, 2007, Millennium Cities Database for Sustainable Transport (Brussels).

International Monetary Fund, 2008, "The Fiscal Implications of Climate Change" (Washington). 
—_, 2011a, Mauritius: Staff Report for the 2011 Article IV Consultation (Washington).

— 2011b, "Revenue Mobilization in Developing Countries" (Washington).

Krupnick, Alan J., Ian W.H. Parry, Margaret Walls, Tony Knowles, and Kristin Hayes, 2010, Toward a New National Energy Policy: Assessing the Options (Washington: Resources for the Future and the National Energy Policy Institute).

Lindsey, Robin, and Erik T. Verhoef, 2000, “Congestion Modeling," in Handbook of Transport Modeling, ed. by K. J. Button and D. A. Hensher (Amsterdam: Pergamon), pp. 353-373.

Mackie, P.J., and others, 2003, Values of Travel Time Savings in the UK: Summary Report, Report to the UK Department for Transport (Leeds: Institute of Transport Studies, University of Leeds.)

Metcalf, Gilbert, E., 2009, "Designing a Carbon Tax to Reduce U.S. Greenhouse Gas Emissions," Review of Environmental Economics and Policy, Vol. 3, No. 1, pp. 63-83.

Menon, Gopinath, 2004, Report on Congestion Pricing in Port Louis, Ministry of Public Infrastructure and Land Transport, Republic of Mauritius.

Meurs, Henk, 2011, "Pricing Kilometers in The Netherlands," Powerpoint Presentation, MuConsult BV, Amersfoort, Holland.

Muller, Nicholas Z., and Robert O. Mendelsohn, 2007, "Measuring the Damages of Air Pollution in the U.S.," Journal of Environmental Economics and Management, Vol. 54, No. 1, 1-14.

National Research Council, 2002, Effectiveness and Impact of Corporate Average Fuel Economy (CAFE) Standards, (Washington: National Academies Press).

National Research Council, 2009, Hidden Costs of Energy: Unpriced Consequences of Energy Production and Use (Washington: National Academies Press).

Organization for Economic Cooperation and Development, 2010, Taxation, Innovation and the Environment (Paris).

Parry, Ian W.H. and Wallace E. Oates, 2000, "Policy Analysis in the Presence of Distorting Taxes," Journal of Policy Analysis and Management, Vol. 19, No. 4, pp. 603-13. 
Parry, Ian W.H., and Jon Strand, 2010, “International Fuel Tax Assessment: An Application to Chile," Discussion Paper (Washington: Resources for the Future).

Parry, Ian W.H., and Roberton C. Williams, forthcoming, "Moving U.S. Climate Policy Forward: Are Carbon Tax Shifts the Only Good Alternative?" in Climate Change and Common Sense: Essays in Honor of Tom Schelling, ed. by Robert Hahn and Alistair Ulph (Oxford: University Press).

Parry, Ian W.H., William A. Pizer and Carolyn Fischer, 2003, "How Large Are the Welfare Gains from Technological Innovation Induced by Environmental Policies?” Journal of Regulatory Economics, Vol. 23, No. 3, pp. 237-55.

Pizer, William A., 2003, "Combining Price and Quantity Controls to Mitigate Global Climate Change,” Journal of Public Economics, Vol. 85, No. 3, pp. 409-34.

Republic of Mauritius, Central Statistics Office, 2009, Digest of Energy and Water Statistics - 2008 (Port Louis).

_, 2010a, Digest of Road Transport and Road Accident Statistics - 2009 (Port Louis). Available via the Internet at: http://www.gov.mu/portal/goc/cso/ei849/toc.htm

— , 2010b, Environmental Statistics - 2009 (Port Louis). Available via the Internet at: www.gov.mu/portal/goc/cso/ei843/toc.htm

Republic of Mauritius, Mauritius Revenue Authority, 2009, Annual Report 2008/2009 (Port Louis). Available via the Internet at: www.gov.mu/portal/sites/mra/index.htm

Republic of Mauritius, National Trasportation Authority, 2010, Road Tax Payable in Respect of Motor Vehicles as from 01 July 2008 (Port Louis). Available via the Internet at: www.gov.mu/portal/site/mpisite/menuitem.40c0fec70451b85a8f77861048a521ca.

Republic of South Africa, National Treasury, 2010, Reducing Greenhouse Gas Emissions: The Carbon Tax Option (Pretoria).

Safirova, Elena, Kenneth Gillingham, Peter Nelson, Ian W.H. Parry, Winston Harrington, and David Mason, 2004, "Welfare and Distributional Effects of HOT Lanes and Other Road Pricing Policies in Metropolitan Washington DC," in Road Pricing: Theory and Practice, ed. by Georgina Santos, Research in Transportation Economics Series, Volume 9, (Oxford: Elsevier), pp. 179-206.

Santos, Georgina 2004a, Road Pricing: Theory and Practice, Research in Transportation Economics 9, Elsevier, pp. 179-206. 
Santos, Georgina, 2004b, "Urban Congestion Charging: A Second-Best Alternative," Journal of Transport Economics and Policy, Vol. 38, No. 3, pp. 345-69.

Santos, Georgina, 2010, "Urban Congestion Charging: A Comparison between London and Singapore," Transport Reviews, Vol. 25, No. 5, pp. 511-34.

Schwartz, Joel, 1994, "Air Pollution and Daily Mortality: A Review and Meta Analysis," Environmental Research, Vol. 64, No. 1, pp. 36-52.

Schrank, David, Tim Lomax, and Shawn Turner, 2010, Urban Mobility Report 2010 (College Station: Texas Transportation Institute, Texas A\&M University).

Small, Kenneth A., 1992, Urban Transportation Economics, Fundamentals of Pure and Applied Economics Series, Volume 51 (Chur: Harwood Academic Press).

Small, Kenneth A., and Erik Verhoef, 2007, The Economics of Urban Transportation (New York: Routledge).

Small, Kenneth A., 2010, "Energy Policies for Passenger Transportation: A Comparison of Costs and Effectiveness,” Discussion Paper (Irvine: University of California, Irvine).

Small, Kenneth A., and Jose A. Gómez-Ibáñez, 1998, "Road Pricing for Congestion Management: The Transition from Theory to Policy," in Road Pricing, Traffic Congestion and the Environment: Issue of Efficiency and Social Feasibility, ed. by K. J. Button and E. T. Verhoef (Cheltenham: Edward Elgar), pp. 213-46.

Small, Kenneth A., and Kurt Van Dender, 2006, "Fuel Efficiency and Motor Vehicle Travel: The Declining Rebound Effect," Energy Journal, Vol. 28, No. 1, pp. 25-52.

Transport for London, 2008, Central London Congestion Charging: Impacts Monitoring, Sixth Annual Report (London).

Train Kenneth, 1985, “Discount Rates in Consumers' Energy-Related Decisions: A Review of the Literature.” Energy, Vol. 10, No. 12, pp. 243-53.

Transportation Research Board, 2006, The Fuel Tax and Alternatives for Transportation Funding (Washington).

United States, Energy Information Administration, 2010, International Energy Statistics (Washington). 
United States, Bureau of Labor Statistics, 2006, National Compensation Survey: Occupational Wages in the United States, June 2005, Bulletin 2581 (Washington).

United States, Department of Transportation, 1997, The Value of Travel Time: Departmental Guidance for Conducting Economic Evaluations (Washington).

United States, Federal Highway Administration, 2000, Addendum to the 1997 Federal Highway Cost Allocation Study Final Report (Washington).

United States, Interagency Working Group on Social Costs of Carbon, 2010, Technical Support Document: Social Cost of Carbon for Regulatory Impact Analysis Under Executive Order 12866 (Washington).

United Nations, 2005, Investing in Development: A Practical Plan to Achieve the Millennium Development Goals (New York).

Viscusi, Kip, and Jospeh E. Aldy, 2003, "The Value of a Statistical Life: A Critical Review of Market Estimates Throughout the World," Journal of Risk and Uncertainty, Vol. 27, No. 1, pp. 5-76.

Wardman, Mark, 2001, “A Review of British Evidence on Time and Service Quality Valuations," Transportation Research E, Vol. 37, No. 2-3, pp. 107-28.

Waters, William G. II, 1996, "Values of Time Savings in Road Transport Project Evaluation," in World Transport Research: Proceedings of $7^{\text {th }}$ World Conference on Transport Research, Vol. 3, ed. by D. Hensher, J. King and T. Oum, (Oxford: Pergamon), pp. 213-223.

World Bank, 2009, Gross National Income Per Capita 2008, Atlas Method and PPP (Washington). 